\title{
Inhibition of HIV-I gene expression by Ciclopirox and Deferiprone, drugs that prevent hypusination of eukaryotic initiation factor $5 \mathrm{~A}$ Mainul Hoque1, Hartmut M Hanauske-Abel ${ }^{2,3}$, Paul Palumbo ${ }^{3,7}$, Deepti Saxena ${ }^{3,7}$, Darlene D'Alliessi Gandolfi" ${ }^{4}$ Myung Hee Park5, Tsafi Pe'ery*1,6 and Michael B Mathews*1
}

Address: ${ }^{1}$ Department of Biochemistry \& Molecular Biology, UMDNJ-New Jersey Medical School, NJ 07103, USA, ${ }^{2}$ Department of Obstetrics, Gynecology \& Women's Health, UMDNJ-New Jersey Medical School, NJ 07103, USA, ${ }^{3}$ Department of Pediatrics, UMDNJ-New Jersey Medical School, NJ 07103, USA, ${ }^{4}$ Department of Chemistry, Manhattanville College, NY 10577, USA, ${ }^{5}$ National Institute for Dental and Craniofacial Research, NIH, MD 20892, USA, ${ }^{6}$ Department of Medicine, UMDNJ-New Jersey Medical School, NJ 07103, USA and ${ }^{7}$ Current Address: Section of Infectious Diseases and International Health, Dartmouth Medical Center, One Medical Center Drive, Lebanon, NH 03756, USA

Email: Mainul Hoque - hoquema@umdnj.edu; Hartmut M Hanauske-Abel - hanaushm@mac.com;

Paul Palumbo - Paul.E.Palumbo@Dartmouth.edu; Deepti Saxena - Deepti.Saxena@Dartmouth.edu; Darlene D'Alliessi

Gandolfi - gandolfid@mville.edu; Myung Hee Park - parkm@mail.nih.gov; Tsafi Pe'ery* - peeryts@umdnj.edu;

Michael B Mathews* - mathews@umdnj.edu

* Corresponding authors

Published: 13 October 2009

Retrovirology 2009, 6:90 doi:10.1 186/1742-4690-6-90

This article is available from: http://www.retrovirology.com/content/6///90

(C) 2009 Hoque et al; licensee BioMed Central Ltd.

This is an Open Access article distributed under the terms of the Creative Commons Attribution License (http://creativecommons.org/licenses/by/2.0), which permits unrestricted use, distribution, and reproduction in any medium, provided the original work is properly cited.

\begin{abstract}
Background: Eukaryotic translation initiation factor elF5A has been implicated in HIV-I replication. This protein contains the apparently unique amino acid hypusine that is formed by the post-translational modification of a lysine residue catalyzed by deoxyhypusine synthase and deoxyhypusine hydroxylase (DOHH). DOHH activity is inhibited by two clinically used drugs, the topical fungicide ciclopirox and the systemic medicinal iron chelator deferiprone. Deferiprone has been reported to inhibit HIV-I replication in tissue culture.
\end{abstract}

Results: Ciclopirox and deferiprone blocked HIV-I replication in PBMCs. To examine the underlying mechanisms, we investigated the action of the drugs on elF5A modification and HIV-I gene expression in model systems. At early times after drug exposure, both drugs inhibited substrate binding to $\mathrm{DOHH}$ and prevented the formation of mature elF5A. Viral gene expression from HIV-I molecular clones was suppressed at the RNA level independently of all viral genes. The inhibition was specific for the viral promoter and occurred at the level of HIV-I transcription initiation. Partial knockdown of elF5A-I by siRNA led to inhibition of HIV-I gene expression that was non-additive with drug action. These data support the importance of elF5A and hypusine formation in HIV-I gene expression.

Conclusion: At clinically relevant concentrations, two widely used drugs blocked HIV-I replication ex vivo. They specifically inhibited expression from the HIV-I promoter at the level of transcription initiation. Both drugs interfered with the hydroxylation step in the hypusine modification of elF5A. These results have profound implications for the potential therapeutic use of these drugs as antiretrovirals and for the development of optimized analogs. 


\section{Background}

Since its discovery in 1981, human immunodeficiency virus type 1 (HIV-1) has led to the death of at least 25 million people worldwide. Although there have been great strides in behavioral prevention and medical treatment of HIV/AIDS, for the last several years the pandemic has claimed about 2.5 million lives annually http:// www.unaids.org and remains unchecked. It is predicted that 20-60 million people will become infected over the next two decades even if there is a $2.5 \%$ annual decrease in HIV infections [1]. Studies of the HIV-1 life cycle led to the development of drugs targeting viral proteins important for viral infection, most notably reverse transcriptase and protease inhibitors. Despite the success of combinations of these drugs in highly active antiretroviral therapy (HAART), the emergence of drug-resistant HIV-1 strains that are facilitated by the high mutation and recombination rates of the virus in conjunction with its prolific replication poses a serious limitation to current treatments. An attractive strategy to circumvent this problem entails targeting host factors that are recruited by the virus to complete its life cycle.

HIV-1 replication requires numerous cellular as well as viral factors, creating a large set of novel potential targets for drug therapy [2-4]. The premise is that compounds directed against a cellular factor that is exploited during HIV-1 gene expression may block viral replication without adverse effects. One such cellular factor is eukaryotic initiation factor 5A (eIF5A, formerly eIF-4D). eIF5A is the only protein known to contain the amino acid hypusine. The protein occurs in two isoforms, of which eIF5A-1 is usually the more abundant $[5,6]$, and has been implicated in HIV-1 replication [7]. Over-expression of mutant eIF5A, or interference with hypusine formation, inhibits HIV-1 replication [8-11]. eIF5A has been implicated in Revdependent nuclear export of HIV-1 RNA [7,8,10,12-15].

Originally characterized as a protein synthesis initiation factor [16], the precise function(s) of eIF5A remain elusive. It has been implicated in translation elongation [1719], the nucleo-cytoplasmic transport of mRNA [20], mRNA stability [21], and nonsense-mediated decay (NMD) [22]. It is tightly associated with actively translating ribosomes $[17,18,21,23,24]$ and is an RNA-binding protein $[25,26]$. Consequently, it has been suggested to function as a specific initiation factor for a subset of mRNAs encoding proteins that participate in cell cycle control $[27,28]$. Its biological roles encompass cancer, maintenance of the cytoskeletal architecture, neuronal growth and survival, differentiation and regulation of apoptosis [16,29-34]. The mature form of eIF5A-1 is associated with intraepithelial neoplasia of the vulva [35] while the eIF5A-2 gene is amplified and expressed at high level in ovarian carcinoma and cancer cell lines
[30,36,37]. Reduction of eIF5A levels slowed proliferation and led to cell cycle arrest in yeast $[27,34,38,39]$. In mammalian cells, inhibitors of hypusine formation arrest the cell cycle at the G1/S boundary [40-43]; they also led to reduced proliferation of leukemic cells and sensitized BcrAbl positive cells to imatinib [44].

Maturation of eIF5A involves both acetylation and hypusination and is necessary for most if not all of its biological roles [45-48]. Hypusine is formed by the posttranslational modification of a specific lysine residue in both eIF5A isoforms throughout the archaea and eukaryota [49]. Hypusine, the enzymes responsible for its formation, and eIF5A itself, are highly conserved in eukaryotes [31,50,51]. This modification of eIF5A entails two consecutive steps (Fig. 1A). In the first step, deoxyhypusine synthase (DHS) catalyzes the cleavage of the polyamine spermidine and the transfer of its 4-aminobutyl moiety to the $\varepsilon$-amino group of lysine-50 (in human eIF5A-1) of the eIF5A precursor, yielding a deoxyhypusine-containing intermediate. In the second step, deoxyhypusine hydroxylase (DOHH) hydroxylates the deoxyhypusyl-eIF5A intermediate to hypusine-containing mature eIF5A using molecular oxygen [49]. DOHH is essential in C. elegans and D. melanogaster, but not in $S$. cerevisiae [52,53], indicative of a requirement for fully modified eIF5A at least in higher eukaryotes. The nonheme iron in the catalytic center of DOHH renders the enzyme susceptible to small molecule inhibitors that conform to the steric restrictions imposed by the active site pocket and interact with the metal via bidentate coordination [54].

The pharmaceuticals ciclopirox (СРX) and deferiprone (DEF) are drugs that block DOHH activity $[11,41,55]$. Both drugs are metal-binding hydroxypyridinones (Fig. 1B). CPX is a topical antifungal (e.g., Batrafen ${ }^{\mathrm{TM}}$ ) and DEF is a medicinal chelator (e.g., Ferriprox ${ }^{\mathrm{TM}}$ ) taken orally for systemic iron overload $[56,57]$. DEF has been shown to inhibit HIV-1 replication in latently-infected ACH-2 cells after phorbol ester induction [11], and in peripheral blood lymphocytes but not in macrophages [58].

Here we report that clinically relevant concentrations of CPX and DEF block HIV-1 infection of human peripheral blood mononuclear cells (PBMCs). We investigated the early effects of the drugs on gene expression from HIV-1 molecular clones in model systems. Both drugs disrupt eIF5A maturation by blocking the binding of DOHH to its substrate. We show that they inhibit gene expression from HIV molecular clones at the RNA level. The drugs act specifically on the viral LTR, with no discernible requirement for viral proteins, and reduce RNA synthesis from the HIV1 promoter at the level of transcription initiation. Consistent with eIF5A being a target for these drugs, partial deple- 


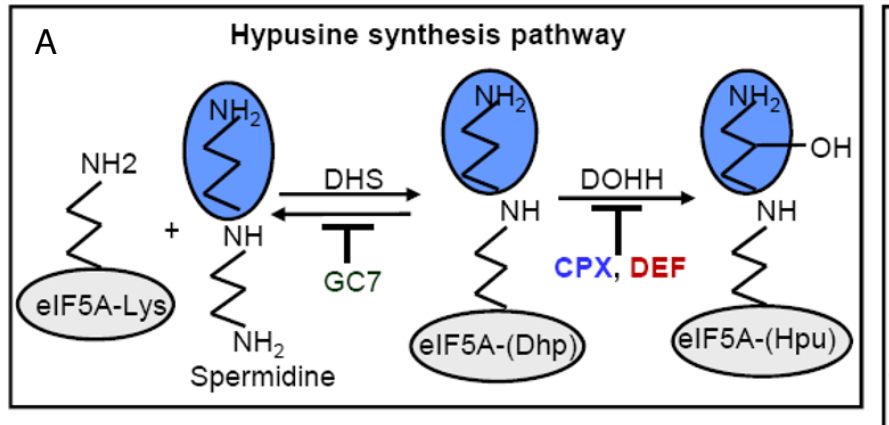

C

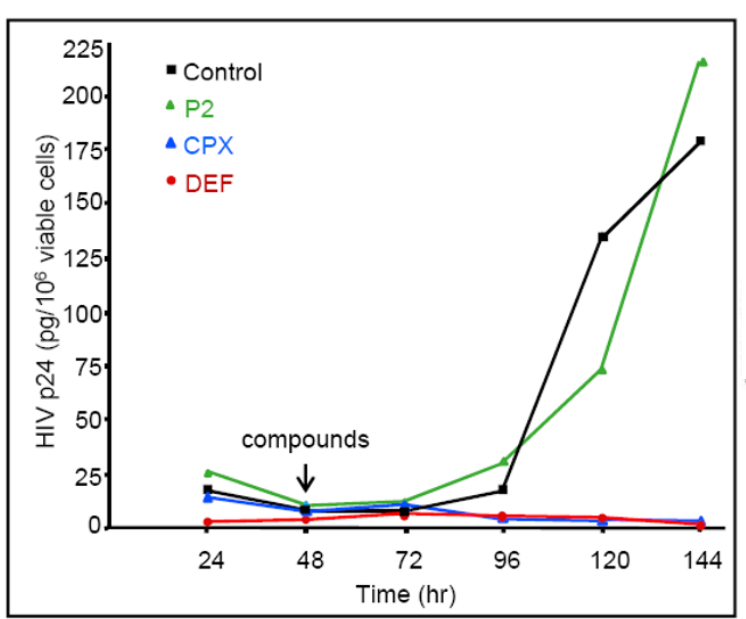

D
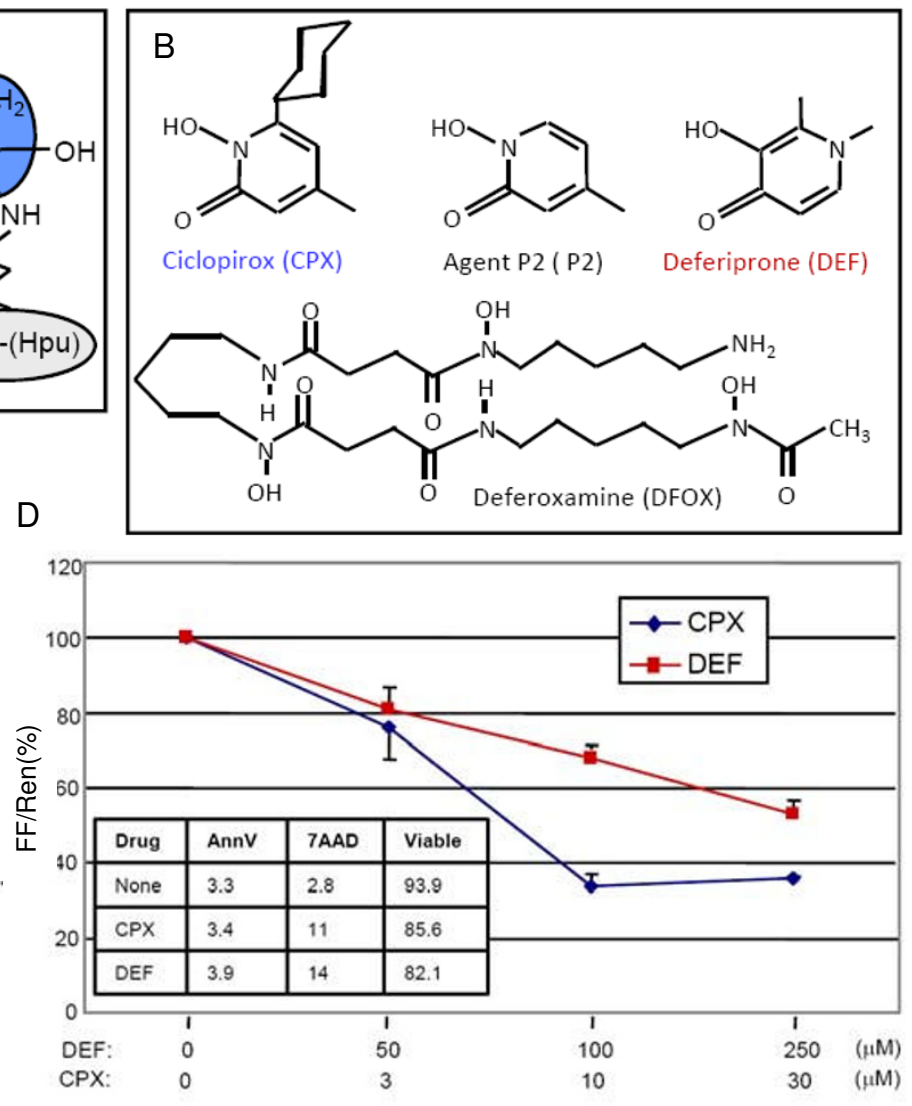

Figure I

Inhibition of HIV replication by drugs that block elF5A modification. A. Hypusination of elF5A (gray) occurs in two steps: the transfer, catalyzed by DHS, of an aminobutyl moiety (blue) from spermidine onto the side chain of elF5A lysine-50, yielding deoxyhypusine (Dhp); and its subsequent hydroxylation, catalyzed by DOHH, yielding hypusine (Hpu). DHS is inhibited by GC7 and DOHH by CPX and DEF, as indicated. B. Structures of CPX, Agent P2, DEF and DFOX. C. CPX and DEF inhibit HIV replication in infected PBMCs. Infected PBMCs that were isolated from a single donor were co-cultured with uninfected PBMCs. CPX $(30 \mu \mathrm{M}), \mathrm{P} 2(30 \mu \mathrm{M})$, or DEF $(250 \mu \mathrm{M})$ were added $48 \mathrm{hr}$ later. Amount of released p24 protein per million viable cells was determined every $24 \mathrm{hr}$. D. CPX and DEF inhibit gene expression from an HIV molecular clone in a dose dependant manner. The molecular clone pNL4-3-LucE- and pCMV-Ren were transfected into 293T cells and drugs were added to the concentrations shown. Dual luciferase assays were conducted at $12 \mathrm{hr}$ post-transfection. Firefly (FF) luciferase expression was normalized to Renilla luciferase (Ren) from pCMV-Ren (mean of 2 experiments in duplicate, \pm SD). Inset shows CPX and DEF effects on apoptosis and cell viability in untransfected 293T cultures as measured by staining with annexin V (AnnV) and 7amino-actinomycin D (7AAD). Data are means of three time points ( 12 , 18 and $24 \mathrm{hr}$ ) presented as percentages.

tion of eIF5A-1 by RNA interference also inhibits HIV-1 promoter-driven gene expression, and this inhibition is non-additive with that caused by the drugs. We conclude that the action of CPX and DEF is at least in part a result of the inhibition of eIF5A hydroxylation, suggesting that cellular DOHH could serve as an antiretroviral target without incurring gross topical or systemic toxicity.

\section{Results}

\section{Antiviral activity of ciclopirox and deferiprone}

To examine the effect of CPX and DEF on HIV-1 propagation, uninfected PBMCs from healthy donors were co-cultured with HIV-infected PBMCs, and virus production was monitored by the $\mathrm{p} 24$ capture assay. In untreated cultures, p24 was first detected at $96 \mathrm{hr}$ and its levels increased until up to $144 \mathrm{hr}$ (Fig. 1C; Control). Addition of CPX and DEF at $48 \mathrm{hr}$, to $30 \mu \mathrm{M}$ and $250 \mu \mathrm{M}$ respectively, reduced p24 to baseline levels. This profound inhibition is due, at least in part, to activation of apoptosis at later stages of infec- 
tion ([11]; unpublished data). These concentrations are within the clinically relevant range and are sufficient to block DOHH activity and eIF5A modification (see below). Agent P2, a chelation homolog of CPX (Fig. 1B), did not impede p24 production (Fig. 1C). These findings suggested that the inhibition of HIV replication by CPX and DEF could be due to inhibition of DOHH and eIF5A maturation.

We selected 293T cells as a model system to explore the relationship between the drugs, eIF5A, and HIV gene expression. These cells efficiently transcribe HIV-1 genes from molecular clones as well as subviral constructs, allowing for early detection of changes in HIV gene expression. To establish the system, we examined the effect of CPX and DEF on the expression of firefly luciferase (FF) from the HIV-1 molecular clone pNL4-3-LucEthat was engineered to carry the FF gene in place of the viral nef gene. The molecular clone was transfected into $293 \mathrm{~T}$ cells together with the pCMV-Ren vector that expresses Renilla luciferase (Ren) from the cytomegalovirus (CMV) immediate early promoter as a control for transfection efficiency and non-specific effects of the compounds. Dual luciferase assays were conducted at $12 \mathrm{hr}$ post-transfection. Results are expressed as relative luciferase activity (FF:Ren). As shown in Figure 1D, the drugs repressed expression from the HIV-1 molecular clone in a dose dependent fashion. Long-term drug exposure leads to pleiotropic effects including apoptosis ([11]; unpublished data), but marginal 293T cell death was observed within $24 \mathrm{hr}$ using these concentrations of CPX and DEF (Fig. 1D, inset). We therefore characterized the action of CPX and DEF on eIF5A and HIV gene expression in 293T cells during the first 12 to $24 \mathrm{hr}$ of drug treatment.

\section{Drug effects on elF5A and DOHH}

To examine the effect of the drugs on the synthesis of modified eIF5A, 293T cells transfected with a FLAGtagged eIF5A expression vector were simultaneously treated with CPX or DEF. FLAG-eIF5A was monitored using NIH-353 and anti-FLAG antibodies (Fig. 2A,B). The NIH-353 antibody reacts preferentially with post-translationally modified eIF5A [35]. CPX reduced the appearance of mature eIF5A over the 3-30 $\mu \mathrm{M}$ concentration range, while DEF was effective at 200-400 $\mu \mathrm{M}$. The drugs did not alter the expression of actin. Comparable results have been obtained in other cell types by spermidine labeling of eIF5A [41]. In addition to the CPX homolog Agent P2, we used deferoxamine (DFOX; Desferal ${ }^{\mathrm{TM}}$ ) as a control compound. DFOX, a metal-binding hydroxamate like CPX and Agent P2 (Fig. 1B), is a globally used medicinal iron chelator [59] that does not inhibit HIV-1 infection [60]. In contrast to CPX and DEF, P2 and DFOX had little or no effect on the appearance of mature FLAG-eIF5A (Fig. $2 \mathrm{~A}, \mathrm{~B})$, indicating that the ability to chelate iron is insuffi- cient to inhibit DOHH and the maturation of eIF5A. None of these compounds reduced the overall expression of the FLAG-eIF5A protein detectably (Fig. 2C), ruling out general inhibitory effects on gene expression. Based on these results, we used $30 \mu \mathrm{M}$ CPX and $250 \mu \mathrm{M}$ DEF for subsequent experiments.

eIF5A forms tight complexes with its modifying enzymes. Unmodified eIF5A (lysine-50) immunoprecipitates with DHS [61,62], and deoxyhypusyl-eIF5A interacts with $\mathrm{DOHH}$ in vitro [63]. We discovered that the deoxyhypusyl-eIF5A:DOHH complex formed in vivo can be detected by immunoprecipitation from cell extracts. Taking advantage of this finding, we tested the effects of the drugs on the enzyme-substrate interaction. FLAG-eIF5A was expressed in 293T cells. Complexes that immunoprecipitated with anti-FLAG antibody were immunoblotted and probed with antibodies against DOHH. Endogenous DOHH co-immunoprecipitated with FLAG-eIF5A, and this association was largely prevented by treatment with CPX or DEF (Fig. 2D, top panel). Consistent with their inability to inhibit eIF5A maturation, neither P2 or DFOX prevented the formation of the eIF5A:DOHH complex. As a further control, we included the DHS inhibitor GC7 $[64,65]$ in this assay. No DOHH was associated with FLAG-eIF5A in the presence of GC7 because it prevents the synthesis of deoxyhypusyl-eIF5A. As expected, none of the compounds affected the immunoprecipitation of FLAG-eIF5A (Fig. 2D, middle panel) or the expression of endogenous eIF5A (Fig. 2D, bottom panel). Reciprocally, the interaction between endogenous eIF5A and tagged DOHH was inhibited by CPX and DEF (Fig. 2E, right). Similarly, the interaction of endogenous eIF5A with tagged DHS was inhibited by GC7 (Fig. 2E, left) but was resistant to CPX and DEF (not shown). We conclude that CPX and DEF, but not P2 or DFOX, target DOHH and inhibit its interaction with its substrate, deoxyhypusyleIF5A.

\section{Inhibition of gene expression from HIV-I molecular clones}

To explore the mechanism whereby CPX and DEF inhibit HIV gene expression, we first examined the specificity of their effect on the expression from the pNL4-3-LucEmolecular clone. Exposure to CPX and DEF repressed expression from the HIV-1 molecular clone by 50\%, as shown above (Fig. 1D), whereas P2 and DFOX were ineffective (Fig. 3A). The drugs had no effect on CMV-driven Renilla luciferase expression. Similar results were obtained in transfected Jurkat $\mathrm{T}$ cells (Fig. 3B). RNase protection assays (RPA) showed that the inhibition of luciferase activity by DEF (Fig. 3C) or CPX (not shown) was reflected in decreased accumulation of FF mRNA, while no change was observed in the accumulation of Ren mRNA from the CMV promoter. Thus, the drugs specifi- 


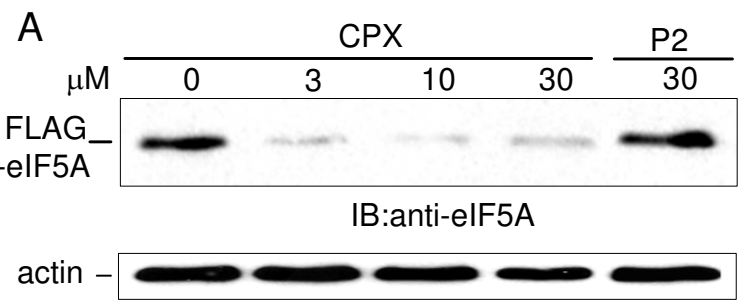

IB:anti-actin

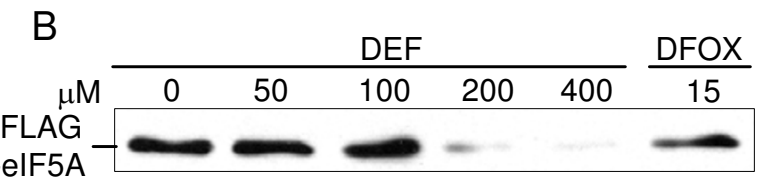

IB:anti-eIF5A

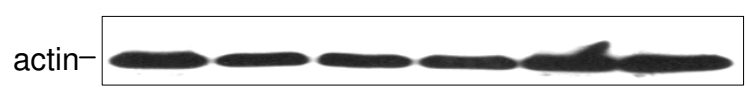

IB:anti-actin

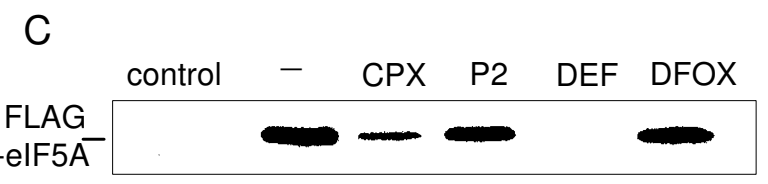

IB:anti-elF5A

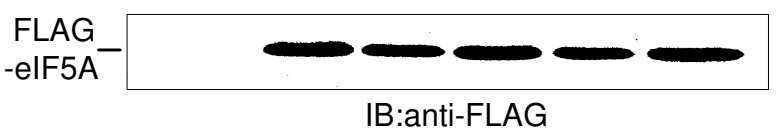

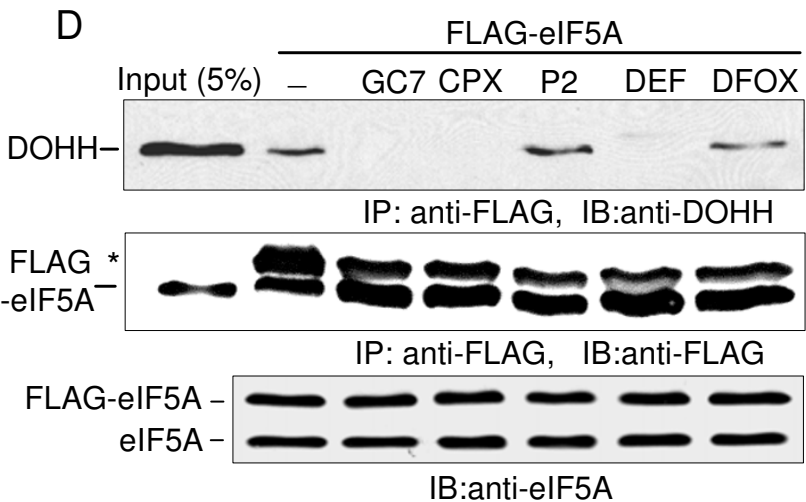

E

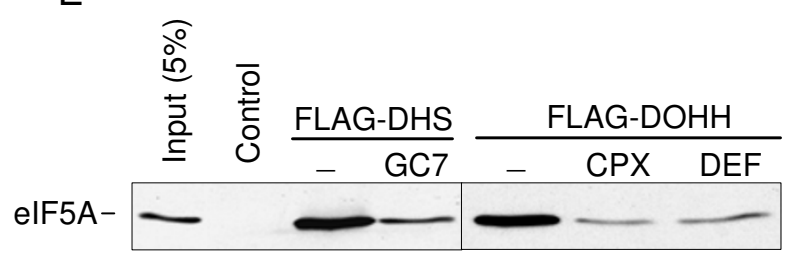

IP:anti-FLAG, IB:anti-elF5A

\section{Figure 2}

Ciclopirox and deferiprone prevent the maturation of elF5A. A. Drug inhibition of elF5A modification in 293T cells. Cells transfected with FLAG-tagged elF5A were untreated or treated with increasing concentrations of CPX as indicated, or with agent P2. At $24 \mathrm{hr}$ post-transfection, whole cell extract (WCE) was analyzed by immunoblotting with the NIH-353 antielF5A antibody (upper panel) and anti-actin antibody (lower panel). B. Cells transfected with FLAG-tagged elF5A were untreated or treated with increasing concentrations of DEF as indicated, or with DFOX. Cells were processed as in A. C. Cells transfected with FLAG-tagged elF5A were treated with CPX (30 $\mu \mathrm{M})$, P2 (30 $\mu \mathrm{M})$, DEF (250 $\mu \mathrm{M})$, DFOX (I0 $\mu \mathrm{M})$, or no drug (-). At $24 \mathrm{hr}$ post-transfection, WCE was analyzed by immunoblotting with the NIH-353 anti-elF5A antibody (upper panel) and anti-FLAG antibody (lower panel). The control culture was transfected with empty vector and no drug was added. D. Inhibition of enzyme-substrate binding. 293T cells transfected with FLAG-elF5A were untreated (-) or treated with GC7 (I0 $\mu$ M) or CPX (30 $\mu \mathrm{M})$, P2 $(30 \mu \mathrm{M})$, DEF $(250 \mu \mathrm{M})$, or DFOX (I0 $\mu \mathrm{M})$. WCE prepared at $24 \mathrm{hr}$ post-transfection was immunoprecipitated with anti-FLAG antibody. Immunoprecipitates were immunoblotted with antibodies against DOHH (top panel) and FLAG (bottom panel). (*)-lgG light chain. E. 293T cells transfected with FLAG-DHS, FLAG-DOHH or empty vector (Control) were treated with GC7, CPX, or DEF, or no drug (-) at the same concentration as in panel D. Immunoprecipitates obtained with anti-FLAG antibody were immunoblotted and probed with anti-elF5A antibody (BD). Input: WCE equivalent to $5 \%$ of the input was immunoblotted as a further control.

cally inhibited luciferase expression from the HIV-1 molecular clone at the RNA level.

Both CPX and DEF also inhibited HIV p24 expression from the molecular clone by $~ 60 \%$, whereas DFOX had no effect (Fig. 3D). We next examined the effects of CPX and DEF on viral mRNA expression. The sensitivity of FF expression from pNL4-3-LucE- to these drugs suggested that the inhibition of RNA accumulation is independent of Rev since the FF sequences are substituted into the nef gene which gives rise to spliced mRNA. To determine whether the action of CPX and DEF is exerted at the level of the accumulation, splicing or nucleo-cytoplasmic distribution of HIV RNA, we transfected pNL4-3-LucE- into 293T cells and monitored spliced and unspliced HIV RNA after drug treatment. RNase protection assays were carried 
out using a probe complementary to the $5^{\prime}$ region of all HIV-1 transcripts [66]. The probe spans the major splice donor site so as to generate two sizes of protected fragments: unspliced RNA protects an RNA fragment 50 nucleotides (nt) longer than that from spliced RNAs (Fig. 4A). CPX and DEF, but not P2, reduced the level of both spliced and unspliced RNAs by 50\% (Fig. 4B). A similar reduction was observed in both the cytoplasmic and nuclear fractions. In contrast, the production of Renilla
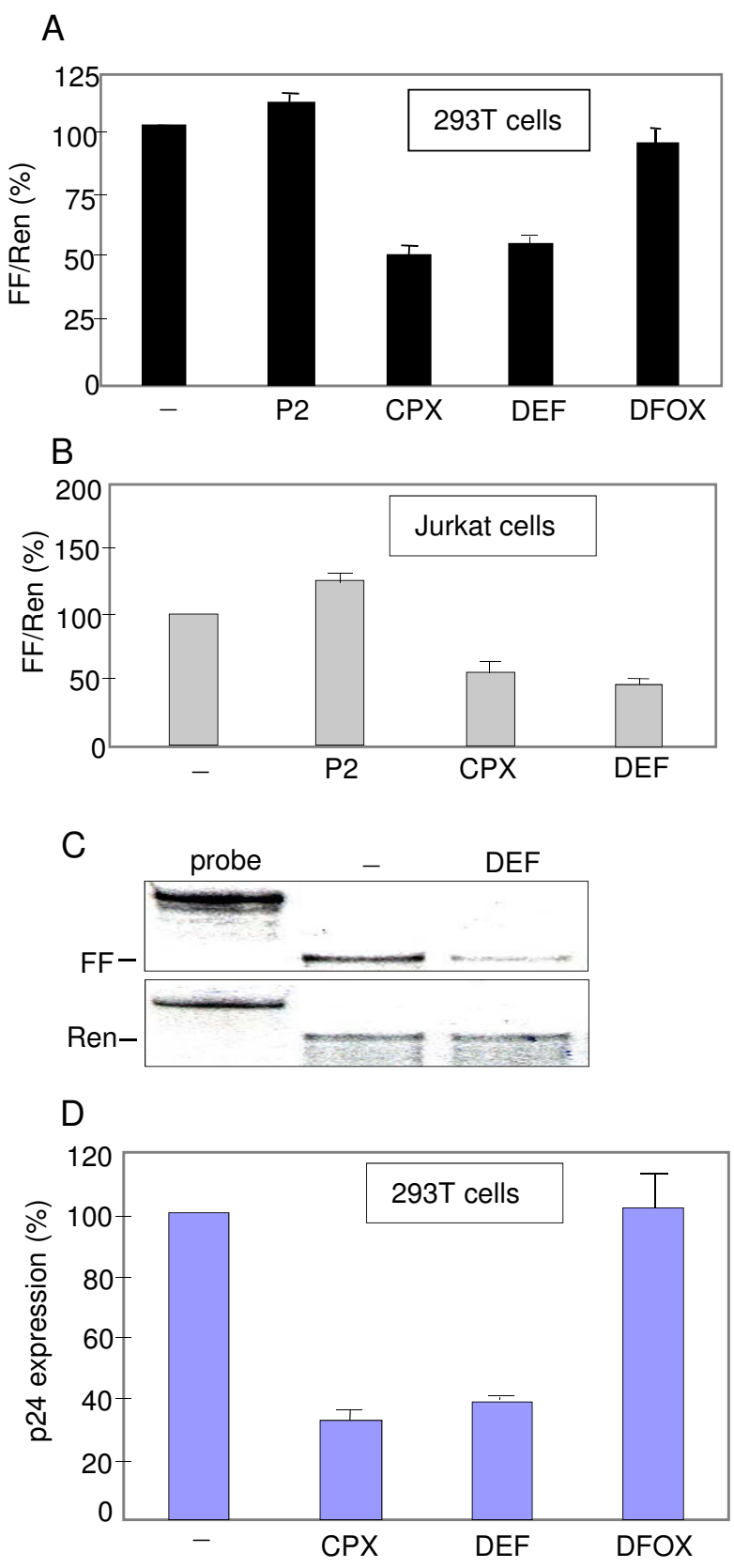

Figure 3

\section{Figure 3}

Drug effects on luciferase expression from an HIV-I molecular clone. A. Comparison of drug effects on luciferase expression from the PNL4-3-LucE- molecular clone in $293 \mathrm{~T}$ cells. The molecular clone pNL4-3-LucE- and pCMVRen were transfected into 293T cells. Drugs were added where indicated at the following concentrations: P2 $(30 \mu \mathrm{M})$, CPX $(30 \mu \mathrm{M})$, DEF $(250 \mu \mathrm{M})$, or DFOX (I5 $\mu \mathrm{M})$. Dual luciferase assays were conducted at $12 \mathrm{hr}$ post-transfection. Firefly (FF) luciferase expression was normalized to Renilla luciferase (Ren) from pCMV-Ren (mean of 2 experiments in duplicate, \pm SD). B. Expression in Jurkat cells was assayed essentially as in panel A. C. Firefly and Renilla luciferase RNA expression was analyzed in $293 \mathrm{~T}$ cells treated as in panel $A$ by RPA using ${ }^{32} \mathrm{P}$ - [UTP] labeled antisense RNA probes corresponding to the $\mathrm{C}$-termini of the $\mathrm{FF}$ and Ren luciferase mRNAs. D. Comparison of drug effects on p24 expression from the pNL4-3-LucE- molecular clone in 293T cells. Drugs were added where indicated to the same concentrations as in A. p24 levels were determined in cell extract at $12 \mathrm{hr}$ post-transfection.

luciferase RNA driven by the CMV promoter was unchanged in the nucleus and cytoplasm after drug treatment (Fig. 4B). Thus, the drugs cause an overall inhibition in HIV RNA expression as early as $12 \mathrm{hr}$ after drug addition.

These experiments did not disclose a significant effect on the splicing or export of viral RNA as a result of treatment with CPX or DEF. Because previous reports indicated that modified eIF5A is involved in the Rev-dependent export of unspliced and underspliced HIV-1 RNAs [7,10,13], we examined whether the drugs affect the splicing or export of viral RNAs mediated by Rev. The rev-defective molecular clone pMRev(-) contains the entire HIV-1 genome but Rev expression is prevented by substitutions in its initiation codon [67]. To compare the inhibitory effect of CPX and DEF in the presence and absence of Rev, cells were transfected with $\mathrm{pMRev}(-)$, either with or without a Rev expression vector, and RNA was analyzed by RPA as above. As expected, in the absence of Rev there was very little unspliced RNA in the cytoplasm although substantial levels were present in the nucleus, and Rev expression increased the level of unspliced RNA in the cytoplasm (Fig. 4C). Treatment with CPX or DEF reduced the levels of both spliced and unspliced RNAs in the nucleus and cytoplasm by 2-3 fold irrespective of the presence or absence of Rev (Fig. 4C). Similar data were obtained in COS7 cells (not shown). These results indicate that the drugs inhibited HIV-1 RNA accumulation by a mechanism that is independent of Rev-mediated viral RNA splicing and export. This finding is consistent with the inhibition of FF expression from pNL4-3-LucE- (Fig. 3). 
A

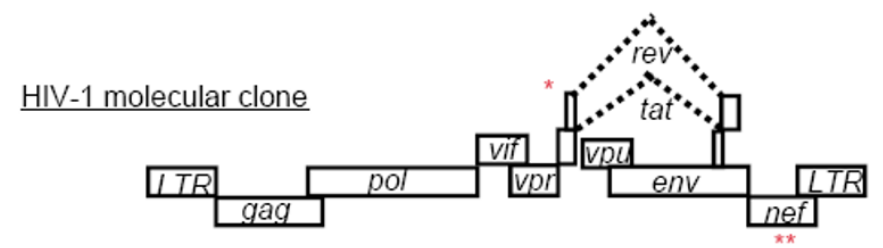

Transcripts:

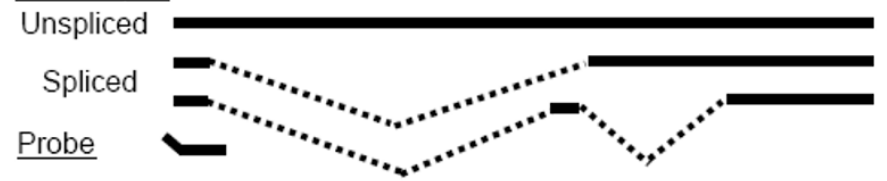

Protected fragments

Unspliced $(U)=$

Spliced (S) -

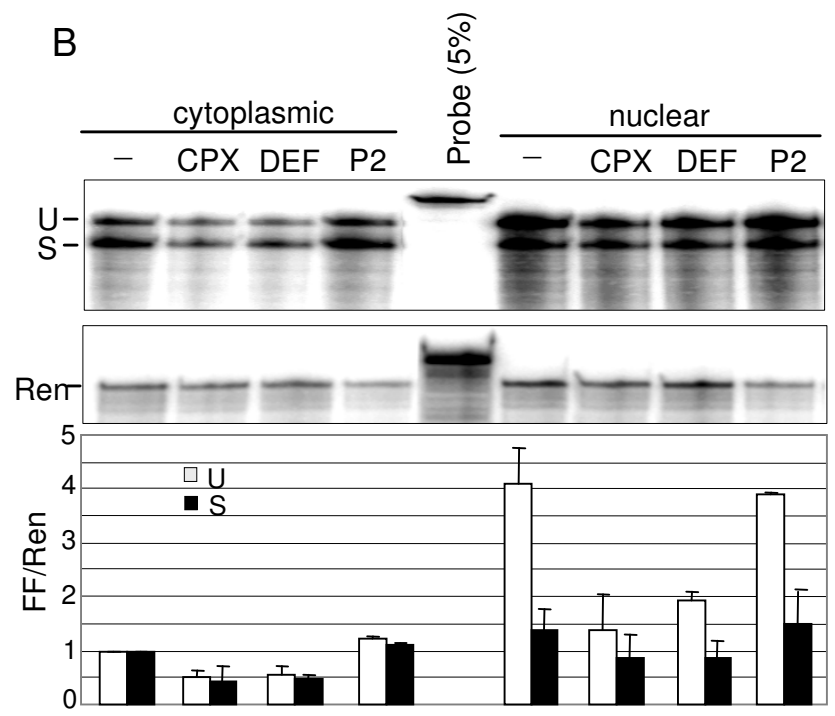

C
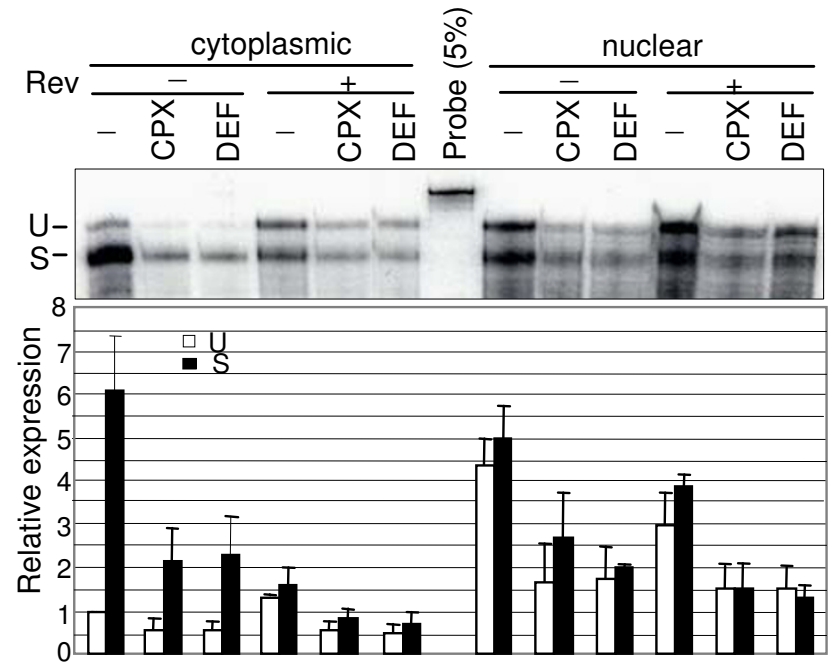

Figure 4

Inhibition of HIV RNA expression from molecular clones. A. Schematic of HIV-I provirus showing major transcripts, the position of the antisense probe, and fragments protected by RPA from spliced $(S)$ and unspliced $(U)$ transcripts. The positions of the Rev start codon mutation in PMRev(-) and the FF substitution in PNL4-3-LucE- are marked with one and two asterisks, respectively. B. Cytoplasmic and nuclear RNA isolated at $12 \mathrm{hr}$ from 293T cells co-transfected with pNL4-3-LucE- and pCMV-Ren. Drugs were added where indicated at concentrations specified in Fig. 2D. RNA was isolated at I $2 \mathrm{hr}$ post-transfection. Autoradiograms display RPA fragments corresponding to HIV and Renilla RNAs (upper and middle panels, respectively). Renilla RNA was analyzed as in Fig. 3. The lower panel displays quantitation of protected spliced and unspliced RNA fragments relative to the Renilla RNA fragment (mean of 2 experiments in duplicate, \pm SD). Probe: undigested probe in an amount equivalent to $5 \%$ of the input to the protection assays was run as a control. C. Effect of Rev. RNA from 293T cells transfected with the Rev-defective HIV molecular clone pMRev(-) together with (+) or without (-) Rev expression vector. RNA was isolated at $15 \mathrm{hr}$ post-transfection. The lower panel displays quantitation of protected spliced and unspliced RNA fragments relative to the cytoplasmic unspliced control RNA (mean of 2 experiments in duplicate, \pm SD). 


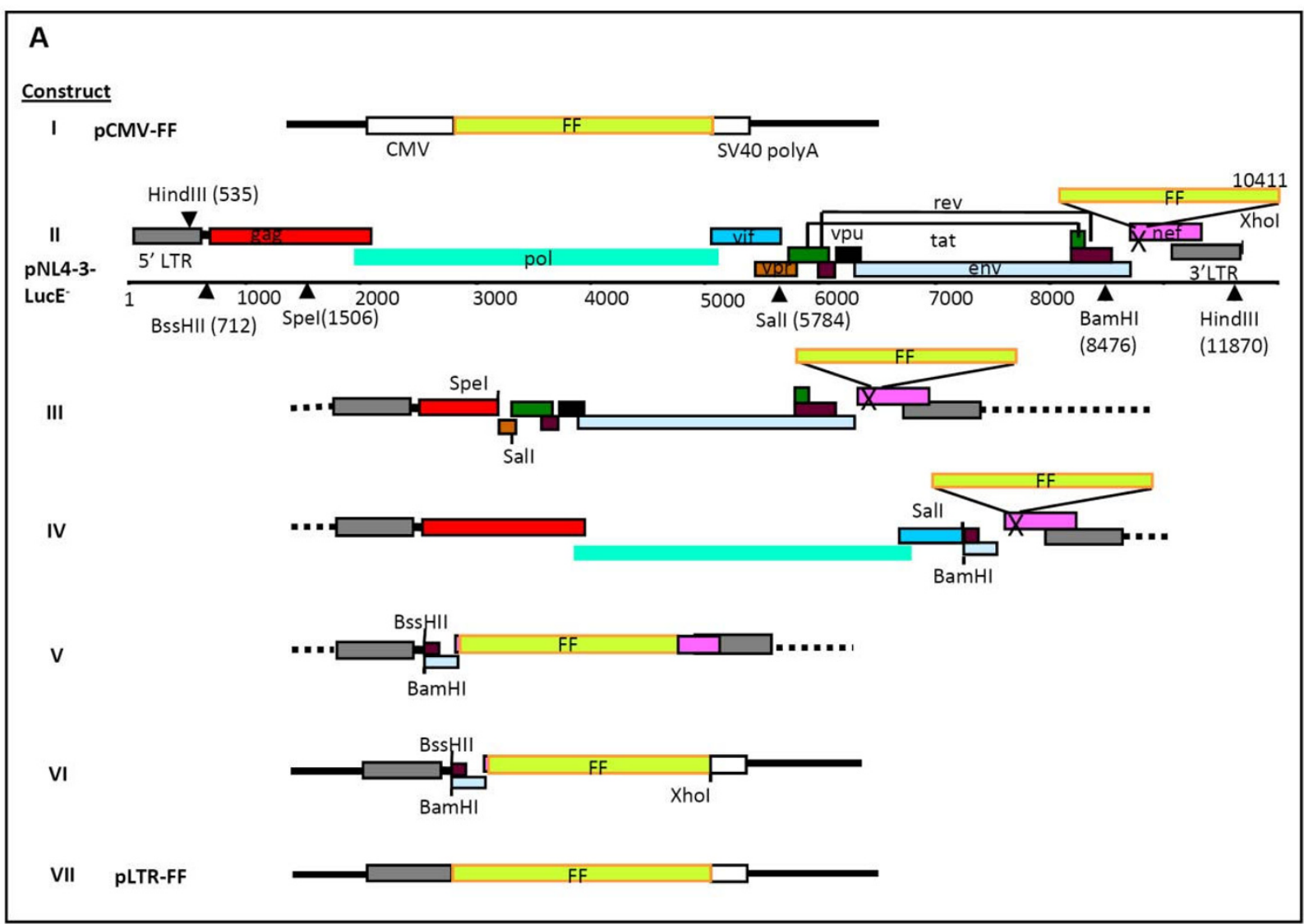

B

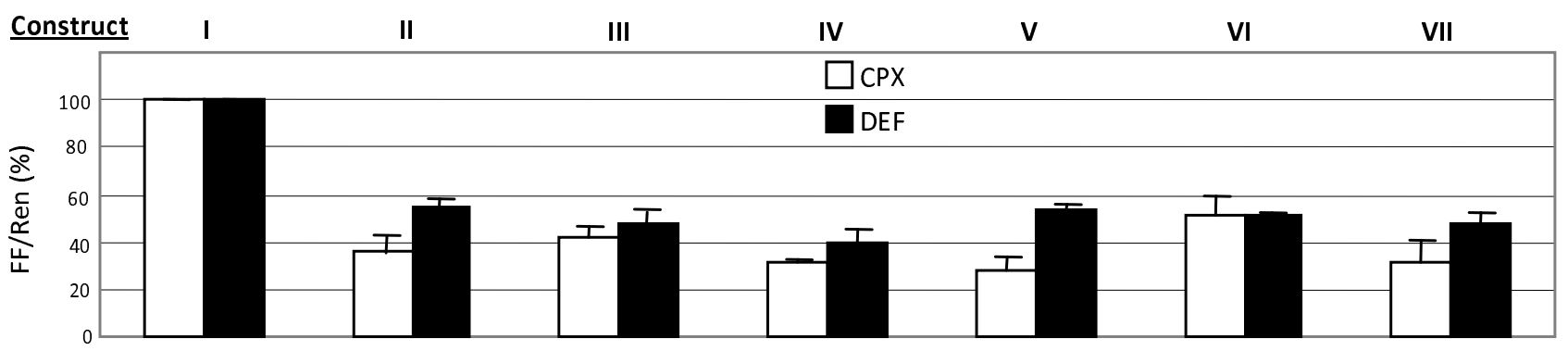

Figure 5

Sequence requirements for the drug sensitivity of the HIV molecular clone. A. Schematic of constructs expressing firefly luciferase from the CMV promoter (construct I, pCMV-FF) or the HIV promoter. Constructs III, IV and V were generated by deleting sequences from pNL4-3-LucE- (construct II). Construct VI was made by replacing the 3'LTR in construct $V$ with the SV40 poly(A) sequence from PGL2TAR. Construct VII is a chimera of pGL2TAR and construct VI. B. CPX and DEF sensitivity of the constructs. Firefly luciferase expression from each construct was normalized to Renilla luciferase expression from pCMV-Ren as in Fig. 3, and presented as a percentage of the control ratio obtained in the absence of drugs. 
Furthermore, since pMRev(-) contains an intact nef gene, we can rule out the possibility that the findings with pNL4-3lucE- are a consequence of the absence of nef from this molecular clone.

\section{Genetic requirements for drug sensitivity}

The data obtained with pMRev(-) excluded involvement in the drug responses of the env mutation, nef deletion and FF gene insertion in pNL4-3lucE-, as well as the rev gene. To search for viral elements that confer sensitivity to CPX and DEF in these short-term experiments, we generated a series of truncations of the HIV-1 genome. Unique restriction sites were exploited to delete major open reading frames from pNL4-3-lucE- (Fig. 5A). Compared to the parental clone (construct II), construct III has a deletion of nt 1506-5784 affecting gag, pol and vif, while construct IV lacks nt 5784 - 8476 eliminating the expression of $v p r, v p u$, tat, rev and $e n v$. These two deletions encompass nearly all of the viral coding sequences. Nevertheless, FF expression from these constructs was inhibited $\geq 50 \%$ by CPX and DEF within $12 \mathrm{hr}$ (Fig. 5B). (Note that Tat-deficient constructs were complemented by co-transfection of a Tat expression vector in these assays.) Subsequently, we produced construct $\mathrm{V}$ by deleting all the open reading frames except for luciferase from the nef coding region. Drug inhibition of this construct, which retains only 1,967 nt of viral sequence, was also $\geq 50 \%$ (Fig. 5 ).

All of these constructs have two intact LTRs, derived from the 5 ' and 3 ' ends of the molecular clone. When the 3'-LTR of construct $\mathrm{V}$, which contains the HIV-1 poly(A) signal, was replaced by a poly(A) signal from SV40 in construct VI, expression was still inhibited $\sim 50 \%$ by CPX and DEF (Fig. 5) indicating that the 3'-LTR is not the determining feature. Construct VI contains $321 \mathrm{nt}$ of env as well as the nef ATG, but these sequences can also be excluded as demonstrated by construct VII (pLTR-FF) in which the 5' LTR is the only segment derived from HIV (Fig. 5). By contrast, expression from pCMV-FF (construct I) was unaffected by CPX and DEF (Fig. 5), consistent with our findings with pCMV-Ren (Figs. 3 and 4). Thus, the inhibition of gene expression by both drugs is specific for the HIV 5'-LTR.

\section{CPX and DEF inhibit transcription initiation at the HIV-I promoter}

Results of the deletion analysis implied that sensitivity to the drugs is conferred by the promoter or another feature in the HIV-1 LTR. A conspicuous feature of HIV transcription is its dependence on the viral Tat protein and the cellular complex P-TEFb (positive transcription elongation factor $b$ ) that cooperate to ensure processive transcription and the formation of long viral transcripts [68]. To determine whether the drugs inhibit at the elongation step, we examined their effect on HIV-1 transcripts generated in COS7 cells co-transfected with pLTR-FF and pCMV-Ren in the presence or absence of a Tat expression vector. Nuclear and cytoplasmic RNA was analyzed in RNase protection assays using a probe complementary to the promoterproximal region of HIV transcripts (Fig. 6A). As expected, short fragments corresponding to RNA of 55-59 nt predominated in the absence of Tat, whereas longer fragments of 83 nt accumulated in its presence (Fig. 6B) $[69,70]$. Similar observations were made in the cytoplasm and nucleus. Treatment with CPX and DEF diminished both signals by $50-80 \%$ irrespective of the presence or absence of Tat (Fig. 6B,C). These results argue against a specific effect at the level of HIV transcription elongation.

To examine the possibility that the drugs decrease the stability of RNA transcribed from the HIV promoter, cells transfected with pLTR-FF were incubated in the presence or absence of CPX. Actinomycin D was added to some cultures $12 \mathrm{hr}$ later to block further transcription, and FF RNA was monitored by RPA at intervals thereafter (Fig. 6D, top panel). FF RNA levels were quantified and normalized to the levels at $12 \mathrm{hr}$ (Fig. 6D, bottom panel). As expected, FF RNA continued to accumulate in the absence of actinomycin $\mathrm{D}$ but declined in its presence. The rate of RNA decay was not affected by the presence of CPX (Fig. 6D). Similar results were obtained with DEF (data not shown). We therefore conclude that the drugs inhibit HIV-1 transcription initiation.

\section{Inhibition of elF5A production reduces HIV gene expression}

The findings described to this point establish a correlation between inhibition of eIF5A modification and inhibition of HIV-1 gene expression. To examine the effect of eIF5A hydroxylation directly we attempted to deplete DOHH by RNA interference. No significant effect on eIF5A modification or HIV gene expression was detected. This is probably because the level of DOHH was not reduced below $60 \%$ (data not shown). We therefore turned to siRNA directed against eIF5A-1 itself. Compared to non-targeted control siRNA, eIF5A-1 siRNA reduced the level of its cognate RNA by $~ 80 \%$ at $24 \mathrm{hr}$ (Fig. 7A). The eIF5A protein level declined more gradually, consistent with its long half-life [71], to a minimum of $~ 30 \%$ of control levels at $96 \mathrm{hr}$ post-siRNA transfection (Fig. 7B). GAPDH mRNA and actin protein levels were unchanged, arguing that eIF5A siRNA does not exert a broad deleterious effect in these cells (Fig. 7A, B).

eIF5A knockdown reduced gene expression from the HIV1 molecular clone by $~ 30 \%$ between 4 and 6 days posttransfection (Fig. 7B, top panel). Although the magnitude of this effect was relatively modest, presumably because of incomplete depletion of eIF5A, two observations attest to its importance. First, the inhibition of HIV-driven gene expression correlated with eIF5A knockdown and recov- 


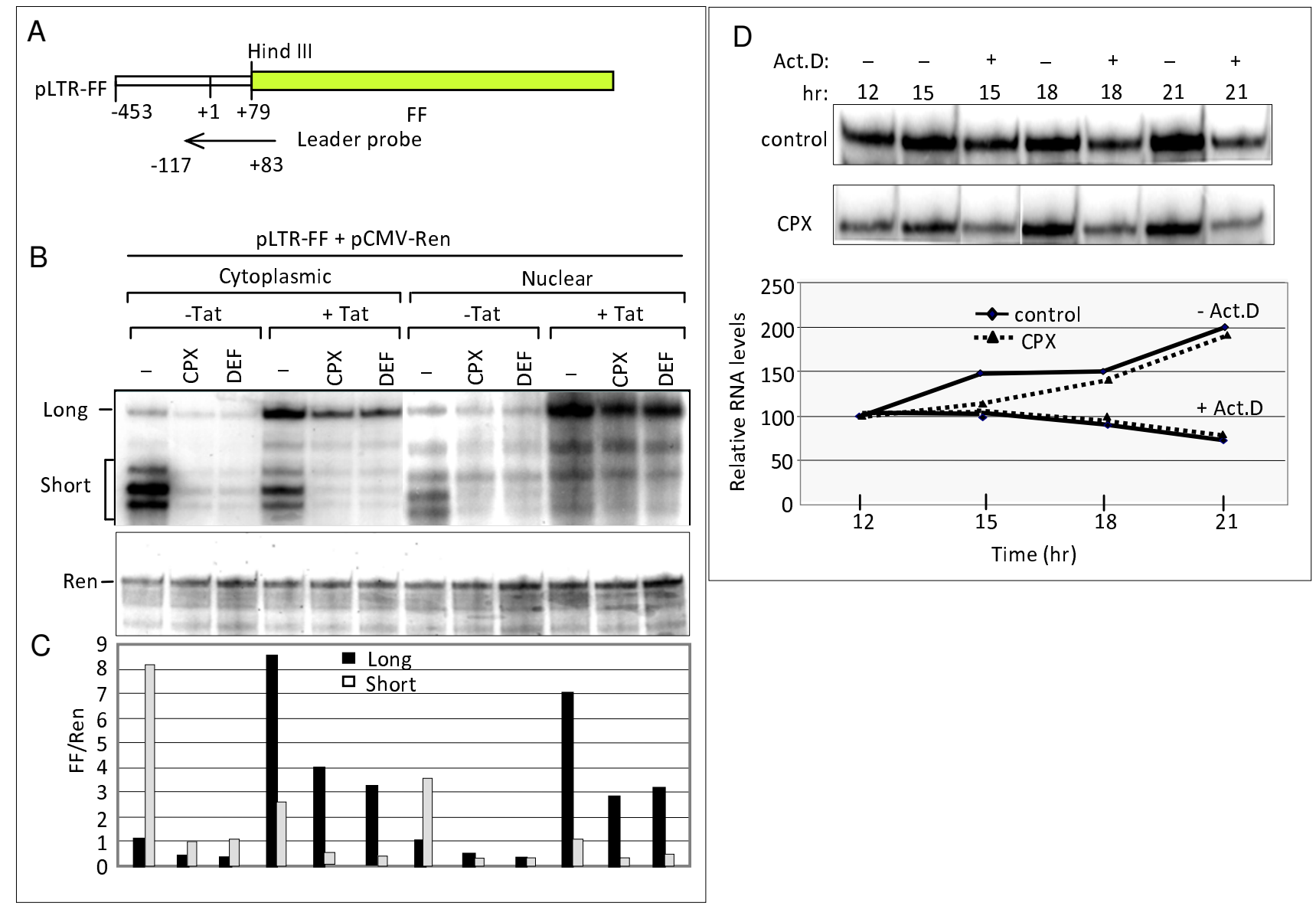

\section{Figure 6}

Inhibition of gene expression by CPX and DEF is promoter specific. A-C. Inhibition is independent of Tat. Total RNA was isolated $15 \mathrm{hr}$ after transfection with PLTR-FF and PCMV-Ren in the absence or presence of Tat expression plasmid. Drugs were added as in Fig. 2D. RPA analysis was conducted by probing with antisense HIV-I leader RNA probe complementary to LTR nt +83 to - II 7 (panel A). Protected fragments corresponding to promoter-proximal (Short) and promoter-distal (Long) transcripts were resolved (panel B) and quantified relative to Renilla RNA (panel C) analyzed as in Fig. 3. D. Stability of RNA transcribed from the HIV promoter in the presence of CPX. Actinomycin D (I $\mu \mathrm{g} / \mathrm{ml})$ was added at $12 \mathrm{hr}$ where indicated. RPA was carried out for FF mRNA as in Fig. 3. Upper panels: expression of FF RNA from the HIV promoter in control and CPX treated cells. Lower panel: FF mRNA decay rate in the presence or absence of CPX plotted relative to levels at 12 hr post-transfection ( $\sim 50 \%$ less in the presence of CPX).

ery (Fig. 7B, lower panel) indicating that targeted reduction of eIF5A expression correlates with inhibition of HIVdriven gene expression. Second, the effects of the drugs and siRNA were not additive. When cells transfected with siRNA for 3 or 4 days were exposed to the drugs for the last $12 \mathrm{hr}$ of this period, eIF5A knockdown did not elicit a further inhibition of HIV-1 gene expression (Fig. 7C). While additional actions cannot be excluded, these observations are consistent with the drugs functioning in the hypusine pathway to inhibit HIV-1 RNA accumulation.

\section{Discussion}

HIV-1 replication can be inhibited by disruption at several different levels of the pathway leading to the post-translational modification of eIF5A with hypusine [10,11,7275]. The formation of hypusine from lysine requires the sequential action of the enzymes DHS and DOHH. We found that two drugs, CPX and DEF, block eIF5A maturation by inhibiting the interaction between DOHH and its substrate, deoxyhypusyl-eIF5A. At clinically used concentrations, the drugs profoundly inhibited HIV-1 infection in long-term cultures and rapidly reduced HIV-1 gene expression in model systems. CPX and DEF both impaired transcription from the HIV-1 promoter independently of 
all known viral genes, a mode of action that would be expected to decrease the likelihood of resistance arising during drug treatment. Enhanced susceptibility to apoptosis was reported in an HIV-1 infected cell line treated with DEF [11], and similar findings have been made in PBMCs with both DEF and CPX (Hanauske-Abel et al., in prepa-
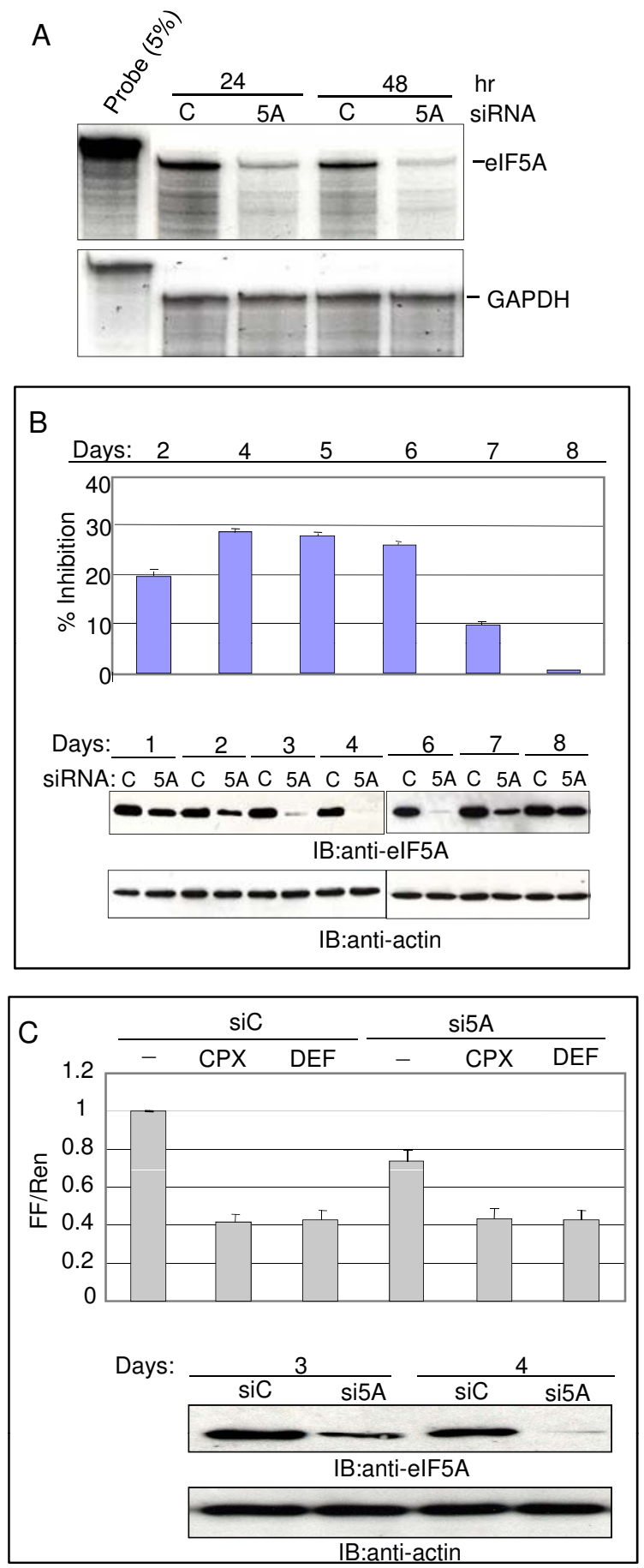

Figure 7

\section{Figure 7}

Depletion of elF5A by siRNA inhibits gene expression from HIV-I molecular clone. A. Depletion of elF5A. 293T cells were transfected with $50 \mathrm{nM}$ of elF5A-I siRNA (5A) or control siRNA (C, with no known complementary sequence in the human genome). Total RNA was isolated from transfected cells at the times indicated and analyzed by RPA using probes for elF5A-I or GAPDH mRNA (panel A). B. Effect of siRNA on HIV gene expression. siRNA-transfected cells were co-transfected with pNL4-3LucE- and pCMV-Ren at I, 3, 4, 5, 6 and 7 days after siRNA transfection and harvested $24 \mathrm{hr}$ later for luciferase assays (top panel) as in Fig. 3. Relative FF/Ren luciferase expression at each time point is shown as a percentage inhibition of the control ratio $(\mathrm{siC})$ obtained in the presence of si5A (triplicate measurements $\pm S D$ ). Parallel cultures were analyzed for elF5A and actin by immunoblotting (bottom panels). $C$. Lack of synergy between siRNA and drugs. siRNA-transfected 293T cells were additionally transfected with pNL4-3LucE- and PCMV-Ren 4 days later and simultaneously treated with CPX or DEF as indicated. Luciferase assays were analyzed as in Fig. 3. Immunoblots for elF5A and actin are shown in the lower panels for days 3 and 4 after siRNA transfection.

ration). Hence we propose that inhibition of HIV-1 transcription by these drugs ultimately leads to loss of viral control over the survival of infected cells and to their apoptotic ablation, as outlined in Figure 8.

\section{CPX and DEF actions}

Despite divergent chemical structures, CPX and DEF both act as potent inhibitors of eIF5A maturation in cells and in vitro $[11,28,41]$. DEF is in clinical use as an orally active medicinal chelator for treatment of transfusion-related iron overload, and CPX is employed as a topical antifungal. After oral medication, the concentration of DEF in serum can reach and exceed $250 \mu \mathrm{M}$ [76]. The topical preparations of CPX, which contain up to $57.5 \mathrm{mM}$ of the agent, achieve levels in excess of $30 \mu \mathrm{M}$ in skin [77]. Our results were obtained at $250 \mu \mathrm{M}$ DEF and $30 \mu \mathrm{M}$ CPX, concentrations well within the range of the drugs' clinically relevant levels. At these concentrations, CPX and DEF can reduce bioavailable intracellular iron levels as determined with an iron-sensitive reporter system, but this effect does not correlate with their antiretroviral action (unpublished data). The medicinal chelator DFOX, which also reduced bioavailable intracellular iron levels, did not inhibit gene expression from the HIV molecular clone (Fig. 3) or block HIV-1 replication when used at clinically relevant levels [60]. This lack of inhibition is consistent with its lack of clinical antiretroviral activity [78]. Several other chelators have been reported to inhibit HIV-1 replication via various possible mechanisms [58,79-82], among them the biologically distinct triden- 


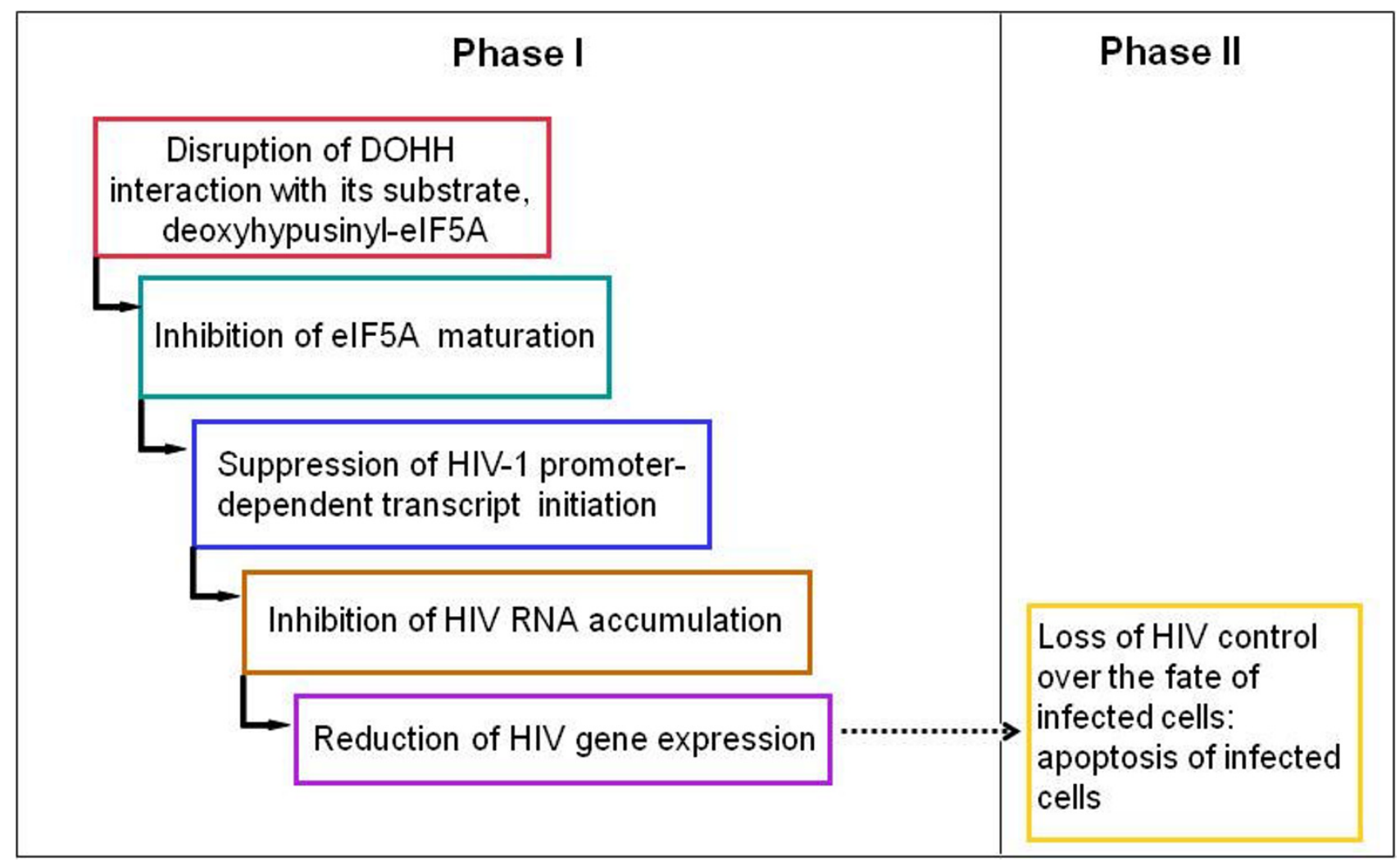

\section{Figure 8}

Scheme for inhibition of HIV-I infection by CPX and DEF. The model integrates results presented in this paper for the early phase of drug action with later events leading to apoptosis ([I I ] Hanauske-Abel et al., in preparation). In phase I the drugs cause a reduction in the expression of HIV proteins, some of which are necessary to prevent apoptosis of HIV infected cells. Apoptosis of infected cells takes place during phase II in the presence of the drugs.

tate drug deferasirox (ICL670) [83]. Agent P2, a bidentate chelation homolog of CPX lacking its hydrophobic cyclohexyl group, displayed little or no activity in our cellbased assays. Thus, the inhibitory action of CPX and DEF on HIV-1 transcription is not merely a consequence of their ability to coordinate and deplete bioavailable iron by bidentate chelation.

CPX and DEF destabilized the interaction between DOHH and deoxyhypusyl-eIF5A, resulting in a marked decrease in the appearance of newly synthesized mature eIF5A (Fig. 2). The drugs did not prevent eIF5A from forming a complex with DHS, which is consistent with the accumulation of deoxyhypusyl-eIF5A in the presence of either drug at concentrations that completely blocked DOHH activity [41]. Neither DFOX nor P2 had any effect on the binding of eIF5A to DOHH, in accordance with their failure to inhibit the formation of hypusinyl-eIF5A. On the other hand, the DHS inhibitor GC7 blocked formation of lysyl-eIF5A:DHS complexes, causing a marked decrease in the levels of deoxyhypusyl-eIF5A and its com- plexes with DOHH. These findings, supported by molecular modeling (Hanauske-Abel et al., unpublished data), lead us to propose that CPX and DEF enter the deoxyhypusine-binding pocket of $\mathrm{DOHH}$, become oriented towards its catalytic iron atom and chelate it. The drugiron chelate is then released from the apoenzyme, which irreversible collapses into a catalytically inactive molecule incapable of binding substrate. Supporting this mechanism, DEF is known to cause release of peptide-bound iron from several non-heme metalloproteins, among them mono- and diferric transferrin, cyclooxygenase, and lipoxygenase [84-86].

\section{Drug effects on HIV-I gene expression}

We analyzed the action of the drugs in a model system consisting of $293 \mathrm{~T}$ cells transfected with HIV-1 molecular clones. Within 12 hours of their addition, CPX and DEF inhibited gene expression from two different molecular clones, impairing transcription from the viral promoter at the level of initiation. This conclusion is supported by several observations: the inhibition was dependent on the 
HIV-1 5'-LTR. No specific effects were detectable on transcription elongation or on downstream mRNA processing, transport or stability. Gene expression from another promoter (the CMV immediate early promoter) and the levels of cellular proteins (actin, eIF5A) were unaffected by CPX and DEF. It is notable that hydroxyurea, which has clinically relevant antiretroviral activity $[87,88]$, also rapidly inhibits transactivation of the HIV promoter to a similar degree [89]. While the concentrations of hydroxyurea required exceed those of CPX by almost two orders of magnitude, the presence of a hydroxyurea-like domain in the CPX structure may imply a common mechanism of action.

eIF5A has also been reported to play post-transcriptional roles in HIV gene expression. The work of Hauber and colleagues identified eIF5A as a cellular cofactor for Rev $[7,10-13]$, leading to the expectation that CPX and DEF would block the export of under-spliced HIV-1 RNAs from the nucleus in a Rev-dependent manner. This prediction was not substantiated in our experiments, however. First, the sensitivity of FF expression from pNL4-3-LucE- to the drugs (Fig. 3) implies a Rev-independent action because the FF luciferase gene is inserted into the HIV-1 nef gene. The HIV-1 nef gene's mRNA is fully spliced and transported independently of Rev. Second, the drugs reduced the accumulation of unspliced and spliced RNA from pNL4-3-LucE- to approximately equal extents and the decrease in RNA accumulation occurred in both nuclear and cytoplasmic compartments (Fig. 4). Third, the drugs inhibited RNA expression from the rev-minus molecular clone pMRev(-) (Fig. 4), and from several deletion constructs that lack rev (Fig. 5). We therefore conclude that Rev is not involved in the effects of CPX and DEF reported here. Similarly, CPX and DEF inhibited the expression of p24, which is translated from incompletely spliced gag mRNA, to about the same extent as FF, generated from spliced mRNA (Fig. 3D). In another study, DEF and mimosine (a naturally occurring analog) were shown to reduce the association of gag mRNA with polysomes, implying an effect on p24 synthesis at the translational level [11]. While this action could be compatible with an eIF5A role in protein synthesis [16-19], it does not comport with the inhibition of transcription documented here. Sharp differences between the experimental systems employed mitigate against direct comparisons. The findings of Andrus and co-workers were made using latently infected ACH-2 cells induced by a phorbol ester [11], which entails multiple effects including sequelae of PKC activation. Moreover, the experiments were conducted over a longer term than those reported here, increasing the opportunity for additional effects to be manifested. The short time span of our experiments was designed to uncover the primary effects of the drugs on HIV-1 gene expression. Nevertheless, it cannot be ruled out that eIF5A also affects other processes and these effects may become more evident with longer drug exposure.

\section{Role of eIF5A}

eIF5A-1 depletion by siRNA reduced HIV-driven gene expression in a manner that was not additive with the action of CPX and DEF. DOHH knockdown by siRNA did not significantly impair HIV gene expression in 293T cells, but expression from the viral promoter was reduced by $\sim 50 \%$ in HeLa cells (data not shown). Knockdown of DHS or of eIF5A-1 in HeLa cells elicited similar effects. Although other drug actions (including the inhibition of other hydroxylases) are not excluded, these findings strengthen the view that the sensitivity of HIV-1 to CPX and DEF results at least in part from their action on eIF5A maturation. How this affects transcription initiation remains to be elucidated. Despite a large body of literature documenting the function of eIF5A at various levels of gene expression, its mechanism(s) of action remain elusive. Interestingly, connections exist between eIF5A and HIV transcription via the cell cycle: hypusine-containing eIF5A is required for G1/S passage as noted above, and HIV-1 is transcribed efficiently in the G2 phase [90-92] although not exclusively so [93]. Thus, inhibition of eIF5A modification could affect both HIV transcription and the cell cycle through eIF5A-dependant cellular components that are common to both pathways. Further work will be required to define the function of mature eIF5A in HIV-1 infection and to establish the sequence of molecular events engendered by CPX and DEF. Our findings provide a mechanistic rationale to study such drugs for their ability to suppress HIV-1 infection in patients, and encourage the development of antiretroviral agents that target the posttranslational formation of hypusine in eIF5A.

\section{Conclusion}

Ciclopirox and deferiprone, two clinically used drugs, block HIV-1 infection. In model systems, the drugs inhibit the enzyme DOHH required for maturation of eIF5A and repress expression from the HIV-1 promoter at the level of transcription initiation. Our results support the concept that drugs targeting DOHH should be tested clinically for HIV-1 inhibition and could be developed as antiretrovirals.

\section{Materials and methods \\ Reagents}

Deferiprone was purchased from Calbiochem. Ciclopirox, deferoxamine and actinomycin $\mathrm{D}$ were purchased from Sigma. Agent P2 was synthesized and characterized as described by Hanauske-Abel et al. (in preparation). Rabbit NIH-353 antibody was raised against mature human eIF5A [35]. Antibody against DOHH was generated by M. H. Park. Anti-eIF5A-1 monoclonal antibody (BD) was 
purchased from BD Biosciences. The anti-FLAG monoclonal antibody M2 and anti-actin antibody were purchased from Sigma.

\section{Cells}

$293 \mathrm{~T}$ and COS7 cells were grown in DME medium (Sigma) and Jurkat cells in RPMI medium (Sigma), both supplemented with penicillin, streptomycin and 8\% FBS. Quantitation of apoptosis and viability was performed with a BD FACSCalibur ${ }^{\mathrm{TM}}$ system using Annexin V-PE Apoptosis Detection Kit I (BD Biosciences, San Jose CA).

\section{Plasmids}

pSP-luct and pSP-rluc were purchased from Promega, Madison. The HIV-1 molecular clone pMRev(-), and the Rev expression vector, plasmid pCMV-Rev, were obtained from the NIH AIDS Research and Reference Reagent Program. FLAG-tagged Rev and eIF5A expression vectors were made by sub-cloning Rev and eIF5A sequences respectively, into the pcDNA3.1FLAG vector. pBSII-HIV+80-340 was constructed by subcloning PCR-amplified HIV-1 sequence (+80-340) from pNL4-3-LucE- [94] into the pBSIIKS+ Bluescript vector. pNL4-3-LucE- truncations were generated by deleting sequences using suitable restriction enzymes. Truncation III was made by deleting sequence from nt 1506 to 5784 using SpeI and SalI enzymes. Similarly, truncations IV (nt 5784 to 8464) and $\mathrm{V}$ (nt 712 to 8464 ) were made with SaII and BamHI and with BssHII and BamHI, respectively. The plasmid pGL2TAR was obtained from Dr. David Price and contains most of the HIV-1 LTR (from KpnI to HindIII). To generate construct VI, the HindIII to PflM1 sequence from pGL2TAR was replaced by the HindIII to XhoI sequence from construct V. Construct VII (pLTR-FF) was made by substituting the sequence between the ClaI and BsgI sites of pGL2TAR with the ClaI to BsgI fragment from construct VI.

\section{HIV-I infection of PBMC cultures}

Uninfected PBMCs from a healthy donor were incubated with infected PBMCs at a 10:1 ratio $\left(1 \times 10^{6}\right.$ cells $)$ in $24-$ well microplates in RPMI medium with antibiotics, glutamate, IL-2 and 10\% fetal calf serum. CPX, DEF, or agent P2 was added $48 \mathrm{hr}$ later. Infected PBMCs were isolated from a highly immunocompromised donor (\#990,135: CD4 count $<5 \%$; HIV RNA in plasma at $\log _{10} 5.5$ copies/ $\mathrm{ml}$ ) using an IRB-approved protocol. Half of the medium supplemented with the appropriate compound was replenished every $24 \mathrm{hr}$ leaving the cell layer undisturbed. A set of wells was harvested every $24 \mathrm{hr}$ for the p24 assay.

\section{Transfection and luciferase assays}

Plasmids were introduced into $2 \times 10^{5} 293 \mathrm{~T}$ cells by transfection using Lipofectamine 2000 (Invitrogen) according to the manufacturer's instructions. Compounds (such as
CPX or DEF) were added simultaneously. Cells were harvested at $12 \mathrm{hr}$ post-transfection, washed with PBS, lysed in $0.15 \mathrm{ml}$ of $1 \times$ passive lysis buffer (Promega), and assayed for luciferase activity using the Promega dual luciferase reporter system according to the manufacturer's instructions. Jurkat cells $\left(1 \times 10^{6}\right.$ cells $)$ were transfected using FuGENE 6 (Roche) according to the manufacturer's instructions and assayed in a similar fashion after pelleting.

\section{Quantitation of p24}

p24 core antigen was quantified in PBMC culture supernatants and transfected cell extracts using a commercially available ELISA (Retrotek HIV-1 p24 ${ }^{\mathrm{Tm}}$; ZeptoMetrix Corp.; Buffalo, NY).

\section{Preparation of nuclear and cytoplasmic RNA}

293 T cells $\left(2 \times 10^{6}\right.$ cells $)$ were seeded in 10 -cm-diameter plates and transfected $20 \mathrm{hr}$ later by using Transfectene (Bio-Rad) and treated with compounds. Cells were harvested at $15 \mathrm{hr}$ post-transfection and suspended in a low salt buffer (10 mM Tris. $\mathrm{HCl}$ pH 7.4, $10 \mathrm{mM} \mathrm{NaCl}, 1.5$ $\mathrm{mM} \mathrm{MgCl}{ }_{2}$, and $0.5 \% \mathrm{NP}-40$ ). Cells were vortexed for 10 $\mathrm{sec}$ and incubated on ice for $10 \mathrm{~min}$. Cell extracts were centrifuged at $500 \times \mathrm{g}$ for $3 \mathrm{~min}$, followed by cytoplasmic and nuclear RNA isolation from the supernatant and the pellet, respectively, using Trizol (Invitrogen) according to the manufacturer's instructions.

\section{RNase protection assay (RPA)}

RPA was performed with $10 \mu \mathrm{g}$ of cytoplasmic RNA and 5 $\mu \mathrm{g}$ of nuclear RNA, using the RPAIII kit from Ambion (Austin, TX) according to the manufacturer's instructions. Synthesis of radiolabeled RNA and protection assays were performed as described previously [95]. To generate antisense RNA probe against the HIV-1 major splice site, firefly luciferase and Renilla luciferase pBSII-KS+HIV (+80341), pSP-luc and pSP-rluc were linearized with HindIII, $\mathrm{XbaI}$ and BsaI, respectively. The resulting probes were 309, 390 and 245 nt long, respectively. The antisense HIV-1 leader RNA probe complementary to $\mathrm{nt}+83$ to -117 of the LTR was generated by subcloning between the XbaI and HindIII sites of the pcDNA3.1 vector. Antisense probe corresponding to the $\mathrm{N}$ terminus of eIF5A was generated by subcloning $250 \mathrm{nt}$ of its cDNA sequence into pcDNA3.1.

\section{Immunoprecipitation and immunoblotting}

Immunoprecipitation and immunoblotting experiments were carried out as described previously [96].

\section{RNA interference}

A pool of four siRNAs targeting eIF5A-1 mRNA (ON-TARGET plus SMARTpool ${ }^{\circledast}$ ), sequence-specific siRNA against DOHH, and control siRNA were purchased from Dharmacon Inc. Cells were transfected with $50 \mathrm{nM}$ siRNA using 
HiPerFect transfection reagent (Qiagen) according to the manufacturer's instructions. The effectiveness of siRNA against specific targets was determined by RPA and immunoblotting.

\section{Competing interests}

The authors declare that they have no competing interests.

\section{Authors' contributions}

$\mathrm{MH}$ designed and conducted the experiments, analyzed the data, generated the figures, and participated in writing the manuscript. HMHA, PP and MBM initiated the project. TP and MBM designed the experiments, analyzed the data, and wrote the manuscript. HMHA analyzed the data and participated in writing the manuscript. DDGA and MHP designed and contributed reagents. MHP, PP and DS provided conceptual input. All authors have read and approved the final manuscript.

\section{Acknowledgements}

We thank Drs. Benjamin Chen, Matija Peterlin and David Price and the NIH AIDS Research and Reference Reagent Program for reagents. We are grateful to Anita Antes for technical assistance. This work was supported by grants from NIH to Tsafi Pe'ery and Michael B. Mathews, and to Hartmut M. Hanauske-Abel as a BIRCWH Scholar (HD-1457).

\section{References}

I. Lagakos SW, Gable AR: Challenges to HIV prevention--seeking effective measures in the absence of a vaccine. $N$ Engl J Med 2008, 358: $1543-1545$.

2. Emerman M, Malim MH: HIV-I regulatory/accessory genes: keys to unraveling viral and host cell biology. Science 1998, 280:1880-1884.

3. Baba M: Recent status of HIV-I gene expression inhibitors. Antiviral Res 2006, 71:30I-306.

4. Lau A, Swinbank KM, Ahmed PS, Taylor DL, Jackson SP, Smith GC, O'Connor MJ: Suppression of HIV-I infection by a small molecule inhibitor of the ATM kinase. Nat Cell Biol 2005, 7:493-500.

5. Jenkins ZA, Haag PG, Johansson HE: Human elF5A2 on chromosome 3q25-q27 is a phylogenetically conserved vertebrate variant of eukaryotic translation initiation factor 5A with tissue-specific expression. Genomics 2001, 71:101-109.

6. Clement PM, Henderson CA, Jenkins ZA, Smit-McBride Z, Wolff EC, Hershey JW, Park MH, Johansson HE: Identification and characterization of eukaryotic initiation factor 5A-2. Eur J Biochem 2003, 270:4254-4263.

7. Ruhl M, Himmelspach M, Bahr GM, Hammerschmid F, Jaksche H, Wolff $B$, Aschauer $H$, Farrington GK, Probst $H$, Bevec $D$, et al.: Eukaryotic initiation factor $5 A$ is a cellular target of the human immunodeficiency virus type I Rev activation domain mediating trans-activation. I Cell Biol 1993, 1 23:1309-1320.

8. Bevec D, Jaksche H, Oft M, Wohl T, Himmelspach M, Pacher A, Schebesta M, Koettnitz K, Dobrovnik M, Csonga R, et al.: Inhibition of HIV-I replication in lymphocytes by mutants of the Rev cofactor elF-5A. Science 1996, 27 I: $1858-1860$.

9. Junker U, Bevec D, Barske C, Kalfoglou C, Escaich S, Dobrovnik M, Hauber J, Bohnlein E: Intracellular expression of cellular elF-5A mutants inhibits HIV-I replication in human T cells: a feasibility study. Hum Gene Ther 1996, 7:1861-1869.

10. Hauber I, Bevec D, Heukeshoven J, Kratzer F, Horn F, Choidas A, Harrer T, Hauber J: Identification of cellular deoxyhypusine synthase as a novel target for antiretroviral therapy. J Clin Invest 2005, I I 5:76-85.

II. Andrus L, Szabo P, Grady RW, Hanauske AR, Huima-Byron T, Slowinska B, Zagulska S, Hanauske-Abel HM: Antiretroviral effects of deoxyhypusyl hydroxylase inhibitors: a hypusine-dependent host cell mechanism for replication of human immunodeficiency virus type I (HIV-I). Biochem Pharmacol 1998, 55: $1807-1818$.

12. Bevec $D$, Hauber J: Eukaryotic initiation factor $\mathbf{5 A}$ activity and HIV-I Rev function. Biol Signals 1997, 6: I24-I33.

13. Rosorius O, Reichart B, Kratzer F, Heger P, Dabauvalle MC, Hauber $\mathrm{J}$ : Nuclear pore localization and nucleocytoplasmic transport of elF-5A: evidence for direct interaction with the export receptor CRMI. J Cell Sci 1999, I I 2(Pt I4):2369-2380.

14. Elfgang C, Rosorius O, Hofer L, Jaksche H, Hauber J, Bevec D: Evidence for specific nucleocytoplasmic transport pathways used by leucine-rich nuclear export signals. Proc Natl Acad Sci USA 1999, 96:6229-6234.

15. Hofmann W, Reichart B, Ewald A, Muller E, Schmitt I, Stauber RH, Lottspeich F, Jockusch BM, Scheer U, Hauber J, Dabauvalle MC: Cofactor requirements for nuclear export of Rev response element (RRE)- and constitutive transport element (CTE)containing retroviral RNAs. An unexpected role for actin. J Cell Biol 200I, I 52:895-9I0.

16. Zanelli CF, Valentini SR: Is there a role for elF5A in translation? Amino Acids 2007, 33:35I-358.

17. Zanelli CF, Maragno AL, Gregio AP, Komili S, Pandolfi JR, Mestriner CA, Lustri WR, Valentini SR: elF5A binds to translational machinery components and affects translation in yeast. Biochem Biophys Res Commun 2006, 348: I358-1366.

18. Jao DL, Chen KY: Tandem affinity purification revealed the hypusine-dependent binding of eukaryotic initiation factor $5 \mathrm{~A}$ to the translating $80 \mathrm{~S}$ ribosomal complex. J Cell Biochem 2006, 97:583-598.

19. Saini P, Eyler DE, Green R, Dever TE: Hypusine-containing protein elF5A promotes translation elongation. Nature 2009, 459: II8-12I.

20. Lipowsky G, Bischoff FR, Schwarzmaier P, Kraft R, Kostka S, Hartmann E, Kutay U, Gorlich D: Exportin 4: a mediator of a novel nuclear export pathway in higher eukaryotes. Embo J 2000, 19:4362-4371.

21. Zuk $D$, Jacobson $A$ : A single amino acid substitution in yeast elf-5A results in mRNA stabilization. Embo J 1998, 17:2914-2925.

22. Schrader R, Young C, Kozian D, Hoffmann R, Lottspeich F: Temperature-sensitive elF5A mutant accumulates transcripts targeted to the nonsense-mediated decay pathway. J Biol Chem 2006, 28 I :35336-35346.

23. Benne R, Brown-Luedi ML, Hershey JW: Purification and characterization of protein synthesis initiation factors elF-I, elF4C, eIF-4D, and elF-5 from rabbit reticulocytes. J Biol Chem 1978, 253:3070-3077.

24. Cooper HL, Park MH, Folk JE, Safer B, Braverman R: Identification of the hypusine-containing protein hy+ as translation initiation factor elF-4D. Proc Natl Acad Sci USA 1983, 80:1854-1857.

25. Liu YP, Nemeroff M, Yan YP, Chen KY: Interaction of eukaryotic initiation factor 5A with the human immunodeficiency virus type I Rev response element RNA and U6 snRNA requires deoxyhypusine or hypusine modification. Biol Signals 1997, 6:166-174.

26. $\mathrm{Xu} A$, Chen $\mathrm{KY}$ : Hypusine is required for a sequence-specific interaction of eukaryotic initiation factor $5 A$ with postsystematic evolution of ligands by exponential enrichment RNA. J Biol Chem 200I, 276:2555-256I.

27. Kang HA, Hershey JW: Effect of initiation factor elF-5A depletion on protein synthesis and proliferation of Saccharomyces cerevisiae. J Biol Chem 1994, 269:3934-3940.

28. Hanauske-Abel HM, Slowinska B, Zagulska S, Wilson RC, StaianoCoico L, Hanauske AR, McCaffrey T, Szabo P: Detection of a subset of polysomal mRNAs associated with modulation of hypusine formation at the GI-S boundary. Proposal of a role for elF-5A in onset of DNA replication. FEBS Lett 1995, 366:92-98.

29. Taylor CA, Sun Z, Cliche DO, Ming H, Eshaque B, Jin S, Hopkins MT, Thai $B$, Thompson JE: Eukaryotic translation initiation factor 5A induces apoptosis in colon cancer cells and associates with the nucleus in response to tumour necrosis factor alpha signalling. Exp Cell Res 2007, 3 I 3:437-449.

30. Clement PM, Johansson HE, Wolff EC, Park MH: Differential expression of elF5A-I and elF5A-2 in human cancer cells. Febs J 2006, 273: I 102-1 II 4 . 
31. Caraglia M, Marra M, Giuberti G, D'Alessandro AM, Budillon A, del Prete S, Lentini A, Beninati S, Abbruzzese A: The role of eukaryotic initiation factor $5 \mathrm{~A}$ in the control of cell proliferation and apoptosis. Amino Acids 2001, 20:91-104.

32. Wei L, Wang Z, Cui T, Yi F, Bu Y, Ding S, Ma Y, Song F: Proteomic Analysis of Cervical Cancer Cells Treated with AdenovirusMediated MDA-7. Cancer Biol Ther 2007, 7:510-6.

33. Huang Y, Higginson DS, Hester L, Park MH, Snyder SH: Neuronal growth and survival mediated by eIF5A, a polyamine-modified translation initiation factor. Proc Natl Acad Sci USA 2007, 1 04:4194-4199.

34. Chatterjee I, Gross SR, Kinzy TG, Chen KY: Rapid depletion of mutant eukaryotic initiation factor $5 \mathrm{~A}$ at restrictive temperature reveals connections to actin cytoskeleton and cell cycle progression. Mol Genet Genomics 2006, 275:264-276.

35. Cracchiolo BM, Heller DS, Clement PM, Wolff EC, Park MH, Hanauske-Abel HM: Eukaryotic initiation factor 5A-I (eIF5A-I) as a diagnostic marker for aberrant proliferation in intraepithelial neoplasia of the vulva. Gynecol Oncol 2004, 94:217-222.

36. Guan XY, Sham JS, Tang TC, Fang Y, Huo KK, Yang JM: Isolation of a novel candidate oncogene within a frequently amplified region at $3 q 26$ in ovarian cancer. Cancer Res 200I, 6 I:3806-3809.

37. Guan XY, Fung JM, Ma NF, Lau SH, Tai LS, Xie D, Zhang Y, Hu L, Wu $Q$ L, Fang $Y$, Sham JS: Oncogenic role of elF-5A2 in the development of ovarian cancer. Cancer Res 2004, 64:4197-4200.

38. Schnier J, Schwelberger HG, Smit-McBride Z, Kang HA, Hershey JW: Translation initiation factor $5 \mathrm{~A}$ and its hypusine modification are essential for cell viability in the yeast Saccharomyces cerevisiae. Mol Cell Biol I991, I I:3 105-31।4.

39. Cano VS, Jeon GA, Johansson HE, Henderson CA, Park JH, Valentini SR, Hershey JW, Park MH: Mutational analyses of human elF5AI--identification of amino acid residues critical for elF5A activity and hypusine modification. Febs / 2008, 275:44-58.

40. Hanauske-Abel HM, Park MH, Hanauske AR, Popowicz AM, Lalande $M$, Folk JE: Inhibition of the G I-S transition of the cell cycle by inhibitors of deoxyhypusine hydroxylation. Biochim Biophys Acta 1994, I 22 I: I I5-124.

4I. Clement PM, Hanauske-Abel HM, Wolff EC, Kleinman HK, Park MH: The antifungal drug ciclopirox inhibits deoxyhypusine and proline hydroxylation, endothelial cell growth and angiogenesis in vitro. Int I Cancer 2002, 100:491-498.

42. Lee Y, Kim HK, Park HE, Park MH, Joe YA: Effect of N I-guanylI,7-diaminoheptane, an inhibitor of deoxyhypusine synthase, on endothelial cell growth, differentiation and apoptosis. $\mathrm{Mol}$ Cell Biochem 2002, 237:69-76.

43. Wang G, Miskimins R, Miskimins WK: Mimosine arrests cells in GI by enhancing the levels of p27(Kipl). Exp Cell Res 2000, 254:64-7I

44. Balabanov S, Gontarewicz A, Ziegler P, Hartmann U, Kammer W, Copland M, Brassat U, Priemer M, Hauber I, Wilhelm T, et al.: Hypusination of eukaryotic initiation factor 5A (elF5A): a novel therapeutic target in BCR-ABL-positive leukemias identified by a proteomics approach. Blood 2007, I09:I70I-I7II.

45. Klier H, Csonga R, Joao HC, Eckerskorn C, Auer M, Lottspeich F, Eder J: Isolation and structural characterization of different isoforms of the hypusine-containing protein elF-5A from HeLa cells. Biochemistry 1995, 34:14693-14702.

46. Shirai A, Matsuyama A, Yashiroda Y, Hashimoto A, Kawamura Y, Arai R, Komatsu $Y$, Horinouchi S, Yoshida M: Global analysis of gel mobility of proteins and its use in target identification. J Biol Chem 2008, 283:10745-10752.

47. Park $\mathrm{MH}$ : The post-translational synthesis of a polyaminederived amino acid, hypusine, in the eukaryotic translation initiation factor 5A (elF5A). J Biochem 2006, I 39: I6I-I69.

48. Chattopadhyay MK, Park MH, Tabor $\mathrm{H}$ : Hypusine modification for growth is the major function of spermidine in Saccharomyces cerevisiae polyamine auxotrophs grown in limiting spermidine. Proc Natl Acad Sci USA 2008, I 05:6554-6559.

49. Wolff EC, Kang KR, Kim YS, Park MH: Posttranslational synthesis of hypusine: evolutionary progression and specificity of the hypusine modification. Amino Acids 2007, 33:34 I-350.

50. Dou QP, Chen KY: Characterization and reconstitution of a cell free system for NAD(+)-dependent deoxyhypusine formation on the $18 \mathrm{kDa}$ eIF-4D precursor. Biochim Biophys Acta 1990, 1036:128-137.
5I. Lee YH, Koh SS, Zhang X, Cheng X, Stallcup MR: Synergy among nuclear receptor coactivators: selective requirement for protein methyltransferase and acetyltransferase activities. Mol Cell Biol 2002, 22:362I-3632.

52. Park JH, Aravind L, Wolff EC, Kaevel J, Kim YS, Park MH: Molecular cloning, expression, and structural prediction of deoxyhypusine hydroxylase: a HEAT-repeat-containing metalloenzyme. Proc Natl Acad Sci USA 2006, I 03:51-56.

53. Patel PH, Costa-Mattioli M, Schulze KL, Bellen HJ: The Drosophila deoxyhypusine hydroxylase homologue nero and its target elF5A are required for cell growth and the regulation of autophagy. J Cell Biol 2009, I 85: I I8I-I I94.

54. Abbruzzese A, Hanauske-Abel HM, Park MH, Henke S, Folk JE: The active site of deoxyhypusyl hydroxylase: use of catecholpeptides and their component chelator and peptide moieties as molecular probes. Biochim Biophys Acta 1991, I077:159-166.

55. Csonga R, Ettmayer P, Auer M, Eckerskorn C, Eder J, Klier H: Evaluation of the metal ion requirement of the human deoxyhypusine hydroxylase from HeLa cells using a novel enzyme assay. FEBS Lett 1996, 380:209-214.

56. Gupta AK, Plott T: Ciclopirox: a broad-spectrum antifungal with antibacterial and anti-inflammatory properties. Int J Dermatol 2004, 43(Suppl I):3-8.

57. Chan JC, Chim CS, Ooi CG, Cheung B, Liang R, Chan TK, Chan V: Use of the oral chelator deferiprone in the treatment of iron overload in patients with $\mathbf{H b} \mathbf{H}$ disease. $\mathrm{Br}$ J Haematol 2006, I33:198-205

58. Georgiou NA, van der Bruggen T, Oudshoorn M, Nottet HS, Marx J], van Asbeck BS: Inhibition of human immunodeficiency virus type I replication in human mononuclear blood cells by the iron chelators deferoxamine, deferiprone, and bleomycin. Infect Dis 2000, I 8 I:484-490.

59. Choudhry VP, Naithani R: Current status of iron overload and chelation with deferasirox. Indian J Pediatr 2007, 74:759-764.

60. Lazdins JK, Alteri E, Klimkait T, Woods-Cook K, Walker MR, Goutte $\mathrm{G}$, Poncioni $\mathrm{B}$ : Lack of effect of desferrioxamine on in-vitro HIV-I replication. Lancet I99|, 338: |34|-|342.

6I. Lee YB, Joe YA, Wolff EC, Dimitriadis EK, Park MH: Complex formation between deoxyhypusine synthase and its protein substrate, the eukaryotic translation initiation factor 5A (elF5A) precursor. Biochem J 1999, 340(Pt I):273-28I.

62. Thompson GM, Cano VS, Valentini SR: Mapping eIF5A binding sites for Dys I and Lial: in vivo evidence for regulation of elF5A hypusination. FEBS Lett 2003, 555:464-468.

63. Kang KR, Kim YS, Wolff EC, Park MH: Specificity of the deoxyhypusine hydroxylase-eukaryotic translation initiation factor (eIF5A) interaction: identification of amino acid residues of the enzyme required for binding of its substrate, deoxyhypusine-containing elF5A. J Biol Chem 2007, 282:8300-8308.

64. Jakus J, Wolff EC, Park MH, Folk JE: Features of the spermidinebinding site of deoxyhypusine synthase as derived from inhibition studies. Effective inhibition by bis- and mono-guanylated diamines and polyamines. I Biol Chem 1993, 268: $13|5|-13 \mid 59$.

65. Umland TC, Wolff EC, Park MH, Davies DR: A new crystal structure of deoxyhypusine synthase reveals the configuration of the active enzyme and of an enzyme.NAD.inhibitor ternary complex. J Biol Chem 2004, 279:28697-28705

66. Zheng $\mathrm{YH}, \mathrm{Yu}$ HF, Peterlin BM: Human p32 protein relieves a post-transcriptional block to HIV replication in murine cells. Nat Cell Biol 2003, 5:61 I-618.

67. Sadaie MR, Benter T, Wong-Staal F: Site-directed mutagenesis of two trans-regulatory genes (tat-III, trs) of HIV-I. Science 1988 , 239:910-913

68. Zhu Y, Pe'ery T, Peng J, Ramanathan Y, Marshall N, Marshall T, Amendt $B$, Mathews $M B$, Price $D H$ : Transcription elongation factor P-TEFb is required for HIV-I tat transactivation in vitro. Genes Dev 1997, I I:2622-2632.

69. Kao SY, Calman AF, Luciw PA, Peterlin BM: Anti-termination of transcription within the long terminal repeat of HIV-I by tat gene product. Nature (London) 1987, 330:489-493.

70. Laspia MF, Rice AP, Mathews MB: HIV-I Tat protein increases transcriptional initiation and stabilizes elongation. Cell 1989. 59:283-292 
7I. Nishimura K, Murozumi K, Shirahata A, Park MH, Kashiwagi K, Igarashi K: Independent roles of elF5A and polyamines in cell proliferation. Biochem J 2005, 385:779-785.

72. Schafer B, Hauber I, Bunk A, Heukeshoven J, Dusedau A, Bevec D, Hauber J: Inhibition of multidrug-resistant HIV-I by interference with cellular S-adenosylmethionine decarboxylase activity. J Infect Dis 2006, I 94:740-750.

73. Chiang PK, McCann PP, Lane JR, Pankaskie MC, Burke DS, Mayers DL: Antihuman Immunodeficiency Virus (HIV-I) Activities of Inhibitors of Polyamine Pathways. J Biomed Sci 1996, 3:78-8I.

74. Marasco CJ Jr, Kramer DL, Miller J, Porter CW, Bacchi CJ, Rattendi $D$, Kucera L, lyer N, Bernacki R, Pera P, Sufrin JR: Synthesis and evaluation of analogues of 5'-([(Z)-4-amino-2-butenyl]methylamino)-5'-deoxyadenosine as inhibitors of tumor cell growth, trypanosomal growth, and HIV-I infectivity. J Med Chem 2002, 45:5 I I2-5122.

75. Hart RA, Billaud JN, Choi SJ, Phillips TR: Effects of I,8-diaminooctane on the FIV Rev regulatory system. Virology 2002, 304:97-104.

76. Kontoghiorghes G], Goddard JG, Bartlett AN, Sheppard L: Pharmacokinetic studies in humans with the oral iron chelator I,2dimethyl-3-hydroxypyrid-4-one. Clin Pharmacol Ther 1990, 48:255-26I.

77. Gupta AK: Ciclopirox: an overview. Int J Dermatol 200I, 40:305-310.

78. Salhi Y, Costagliola D, Rebulla P, Dessi C, Karagiorga M, Lena-Russo $D$, de Montalembert M, Girot R: Serum ferritin, desferrioxamine, and evolution of HIV-I infection in thalassemic patients. J Acquir Immune Defic Syndr Hum Retrovirol 1998, 18:473-478.

79. Debebe Z, Ammosova T, Jerebtsova M, Kurantsin-Mills J, Niu X, Charles S, Richardson DR, Ray PE, Gordeuk VR, Nekhai S: Iron chelators ICL670 and $3 I I$ inhibit HIV-I transcription. Virology 2007, 367:324-333.

80. Sappey C, Boelaert JR, Legrand-Poels S, Forceille C, Favier A, Piette ]: Iron chelation decreases NF-kappa B and HIV type I activation due to oxidative stress. AIDS Res Hum Retroviruses 1995, I I:1049-106I.

81. van Asbeck BS, Georgiou NA, Bruggen T van der, Oudshoorn M, Nottet HS, Marx J]: Anti-HIV effect of iron chelators: different mechanisms involved. J Clin Virol 2001, 20:|4|-|47.

82. Georgiou NA, Bruggen T van der, Oudshoorn M, Hider RC, Marx JJ, van Asbeck BS: Human immunodeficiency virus type I replication inhibition by the bidentate iron chelators CP502 and CP5 I I is caused by proliferation inhibition and the onset of apoptosis. Eur J Clin Invest 2002, 32(Suppl I):91-96.

83. Nick H, Acklin P, Lattmann R, Buehlmayer P, Hauffe S, Schupp J, Alberti D: Development of tridentate iron chelators: from desferrithiocin to ICL670. Curr Med Chem 2003, I 0:1065-1076.

84. Li Y, Harris WR: Iron removal from monoferric human serum transferrins by I, 2-dimethyl-3-hydroxypyridin-4-one, Ihydroxypyridin-2-one and acetohydroxamic acid. Biochim Biophys Acta 1998, I387:89-102.

85. Barradas MA, Jeremy JY, Kontoghiorghes G], Mikhailidis DP, Hoffbrand AV, Dandona P: Iron chelators inhibit human platelet aggregation, thromboxane A2 synthesis and lipoxygenase activity. FEBS Lett 1989, 245:105-109.

86. Kontoghiorghes GJ, Evans RW: Site specificity of iron removal from transferrin by alpha-ketohydroxypyridine chelators. FEBS Lett 1985, 189:14|-144.

87. Lisziewicz J, Foli A, Wainberg M, Lori F: Hydroxyurea in the treatment of HIV infection: clinical efficacy and safety concerns. Drug Saf 2003, 26:605-624.

88. Garcia F, Plana M, Arnedo M, Ortiz GM, Miro JM, Lopalco L, Lori F, Pumarola T, Gallart T, Gatell JM: A cytostatic drug improves control of HIV-I replication during structured treatment interruptions: a randomized study. AIDS 2003, I 7:43-5I.

89. Calzado MA, MacHo A, Lucena C, Munoz E: Hydroxyurea inhibits the transactivation of the HIV-long-terminal repeat (LTR) promoter. Clin Exp Immunol 2000, I 20:317-323.

90. Gummuluru S, Emerman M: Cell cycle- and Vpr-mediated regulation of human immunodeficiency virus type I expression in primary and transformed T-cell lines. J Virol 1999, 73:5422-5430.

91. Wang D, de la Fuente C, Deng L, Wang L, Zilberman I, Eadie C, Healey M, Stein D, Denny T, Harrison LE, et al.: Inhibition of human immunodeficiency virus type I transcription by chemical cyclin-dependent kinase inhibitors. J Virol 200I, 75:7266-7279.

92. Thierry S, Marechal V, Rosenzwajg M, Sabbah M, Redeuilh G, Nicolas JC, Gozlan J: Cell cycle arrest in $\mathbf{G 2}$ induces human immunodeficiency virus type I transcriptional activation through histone acetylation and recruitment of CBP, NF-kappaB, and cJun to the long terminal repeat promoter. J Virol 2004 , 78: $12198-12206$.

93. Kundu M, Sharma S, De Luca A, Giordano A, Rappaport J, Khalili K, Amini S: HIV-I Tat elongates the GI phase and indirectly promotes HIV-I gene expression in cells of glial origin. J Biol Chem 1998, 273:8130-8136.

94. Chen BK, Saksela K, Andino R, Baltimore D: Distinct modes of human immunodeficiency virus type I proviral latency revealed by superinfection of nonproductively infected cell lines with recombinant luciferase-encoding viruses. J Virol 1994, 68:654-660.

95. Young TM, Wang Q, Pe'ery T, Mathews MB: The Human I-mfa Domain-Containing Protein, HIC, Interacts with Cyclin TI and Modulates P-TEFb-Dependent Transcription. Mol Cell Biol 2003, 23:6373-6384.

96. Hoque M, Young TM, Lee CG, Serrero G, Mathews MB, Pe'ery T: The Growth Factor Granulin Interacts with Cyclin TI and Modulates P-TEFb-Defendent Transcription. Mol Cell Biol 2003, 23: I688-1702.

Publish with Bio Med Central and every scientist can read your work free of charge

"BioMed Central will be the most significant development for disseminating the results of biomedical research in our lifetime. "

Sir Paul Nurse, Cancer Research UK

Your research papers will be:

- available free of charge to the entire biomedical community

- peer reviewed and published immediately upon acceptance

- cited in PubMed and archived on PubMed Central

- yours - you keep the copyright 